\title{
Historical (1700-2012) global multi-model estimates of the fire emissions from the Fire Modeling Intercomparison Project (FireMIP)
}

Fang Li ${ }^{1}$, Maria Val Martin ${ }^{2}$, Meinrat O. Andreae ${ }^{3,4}$, Almut Arneth ${ }^{5}$, Stijn Hantson ${ }^{6,5}$, Johannes W. Kaiser ${ }^{7,3}$, Gitta Lasslop $^{8}$, Chao Yue ${ }^{9,10}$, Dominique Bachelet ${ }^{11}$, Matthew Forrest ${ }^{8}$, Erik Kluzek ${ }^{12}$, Xiaohong Liu ${ }^{13}$, Stephane Mangeon ${ }^{14, a}$, Joe R. Melton ${ }^{15}$, Daniel S. Ward ${ }^{16}$, Anton Darmenov ${ }^{17}$, Thomas Hickler ${ }^{8,18}$, Charles Ichoku ${ }^{19}$, Brian I. Magi ${ }^{20}$, Stephen Sitch ${ }^{21}$, Guido R. van der Werf ${ }^{22}$, Christine Wiedinmyer ${ }^{23}$, and Sam S. Rabin

${ }^{1}$ International Center for Climate and Environment Sciences, Institute of Atmospheric Physics, Chinese Academy of Sciences, Beijing, China

${ }^{2}$ Leverhulme Center for Climate Change Mitigation, Department of Animal \& Plant Sciences, Sheffield University, Sheffield, UK

${ }^{3}$ Biogeochemistry Department, Max Planck Institute for Chemistry, Mainz, Germany

${ }^{4}$ Department of Geology and Geophysics, King Saud University, Riyadh, Saudi Arabia

${ }^{5}$ Karlsruhe Institute of Technology (KIT), Institute of Meteorology and Climate research, Atmospheric Environmental Research, Garmisch-Partenkirchen, Germany

${ }^{6}$ Geospatial Data Solutions Center, University of California, Irvine, CA, USA

${ }^{7}$ Deutscher Wetterdienst, Offenbach, Germany

${ }^{8}$ Senckenberg Biodiversity and Climate Research Institute (BiK-F), Senckenberganlage, Germany

${ }^{9}$ State Key Laboratory of Soil Erosion and Dryland Farming on the Loess Plateau,

Northwest A\&F University, Yangling, Shanxi, China

${ }^{10}$ Laboratoire des Sciences du Climat et de l'Environnement, LSCE/IPSL, CEA-CNRS-UVSQ,

Université Paris-Saclay, Gif-sur-Yvette, France

${ }^{11}$ Biological and Ecological Engineering, Oregon State University, Corvallis, OR, USA

${ }^{12}$ National Center for Atmospheric Research, Boulder, CO, USA

${ }^{13}$ Department of Atmospheric Science, University of Wyoming, Laramie, WY, USA

${ }^{14}$ Department of Physics, Imperial College London, London, UK

${ }^{15}$ Climate Research Division, Environment and Climate Change Canada, Victoria, BC, Canada

${ }^{16}$ Karen Clark and Company, Boston, MA, USA

${ }^{17}$ Global Modeling and Assimilation Office, NASA Goddard Space Flight Center, Greenbelt, MD, USA

${ }^{18}$ Department of Physical Geography, Goethe University, Frankfurt am Main, Germany

${ }^{19}$ Department of Interdisciplinary Studies, Howard University, NW, Washington, DC, USA

${ }^{20}$ Department of Geography and Earth Sciences, University of North Carolina at Charlotte, Charlotte, NC, USA

${ }^{21}$ College of Life and Environmental Sciences, University of Exeter, Exeter, UK

${ }^{22}$ Faculty of Science, Vrije Universiteit, Amsterdam, the Netherlands

${ }^{23}$ Cooperative Institute for Research in Environmental Sciences, University of Colorado Boulder, Boulder, CO, USA

${ }^{\mathrm{a}}$ now at: CSIRO, Data61, Brisbane, QLD, Australia

Correspondence: Fang Li (lifang@mail.iap.ac.cn)

Received: 15 January 2019 - Discussion started: 8 March 2019

Revised: 15 August 2019 - Accepted: 9 September 2019 - Published: 9 October 2019 
Abstract. Fire emissions are a critical component of carbon and nutrient cycles and strongly affect climate and air quality. Dynamic global vegetation models (DGVMs) with interactive fire modeling provide important estimates for longterm and large-scale changes in fire emissions. Here we present the first multi-model estimates of global gridded historical fire emissions for 1700-2012, including carbon and 33 species of trace gases and aerosols. The dataset is based on simulations of nine DGVMs with different state-of-theart global fire models that participated in the Fire Modeling Intercomparison Project (FireMIP), using the same and standardized protocols and forcing data, and the most upto-date fire emission factor table based on field and laboratory studies in various land cover types. We evaluate the simulations of present-day fire emissions by comparing them with satellite-based products. The evaluation results show that most DGVMs simulate present-day global fire emission totals within the range of satellite-based products. They can capture the high emissions over the tropical savannas and low emissions over the arid and sparsely vegetated regions, and the main features of seasonality. However, most models fail to simulate the interannual variability, partly due to a lack of modeling peat fires and tropical deforestation fires. Before the 1850 s, all models show only a weak trend in global fire emissions, which is consistent with the multi-source merged historical reconstructions used as input data for CMIP6. On the other hand, the trends are quite different among DGVMs for the 20th century, with some models showing an increase and others a decrease in fire emissions, mainly as a result of the discrepancy in their simulated responses to human population density change and land use and land cover change (LULCC). Our study provides an important dataset for further development of regional and global multi-source merged historical reconstructions, analyses of the historical changes in fire emissions and their uncertainties, and quantification of the role of fire emissions in the Earth system. It also highlights the importance of accurately modeling the responses of fire emissions to LULCC and population density change in reducing uncertainties in historical reconstructions of fire emissions and providing more reliable future projections.

\section{Introduction}

Fire is an intrinsic feature of terrestrial ecosystem ecology, occurring in all major biomes of the world soon after the appearance of terrestrial plants over 400 million years ago (Scott and Glasspool, 2006; Bowman et al., 2009). Fire emissions affect the Earth system in several important ways. First, chemical species emitted from fires are a key component of the global and regional carbon budgets (Bond-Lamberty et al., 2007; Ciais et al., 2013; Kondo et al., 2018), a major source of greenhouse gases (Tian et al., 2016), and the largest contributor of primary carbonaceous aerosols globally (An- dreae and Rosenfeld, 2008; Jiang et al., 2016). Second, by changing the atmospheric composition, fire emissions affect the global and regional radiation balance and climate (Ward et al., 2012; Tosca et al., 2013; Jiang et al., 2016; Grandey et al., 2016; McKendry et al., 2019; Hamilton et al., 2018; Thornhill et al., 2018). Third, fire emissions change the terrestrial nutrient and carbon cycles by altering the deposition of nutrients (e.g., nitrogen, phosphorus), surface ozone concentration, and meteorological conditions (Mahowald et al., 2008; Chen et al., 2010; McKendry et al., 2019; Yue and Unger, 2018). In addition, they degrade the air quality (Val Martin et al., 2015; Knorr et al., 2017), which poses a significant risk to human health and has been estimated to result in at least $\sim 165000$, and more likely $\sim 339000$, premature deaths per year globally (Johnston et al., 2012; Marlier et al., 2013; Lelieveld et al., 2015).

To date, only emissions from individual fires or smallscale fire complexes can be directly measured from field campaigns and laboratory experiments (Andreae and Merlet, 2001; Yokelson et al., 2013; Stockwell et al., 2016; Andreae, 2019). Regionally and globally, fire emissions are often estimated based on satellite observations, fire proxy records, and numerical models, even though some attempts have been made to bridge the gap between local observations and regional estimations using combinations of aircraftand ground-based measurements from field campaigns (e.g., SAMBBA, ARCTAS), satellite-based inventories, and chemical transport models (e.g., Fisher et al., 2010; Reddington et al., 2019; Konovalov et al., 2018). Satellite-based fire emission estimates are primarily derived from satellite observations of burned area, active fire counts, and/or fire radiative power, and are sometimes constrained by satellite observations of aerosol optical depth (AOD), $\mathrm{CO}$, or $\mathrm{CO}_{2}$ (Wiedinmyer et al., 2011; Kaiser et al., 2012; Krol et al., 2013; Konovalov et al., 2014; Ichoku and Ellison, 2014; Darmenov and da Silva, 2015; van der Werf et al., 2017; Heymann et al., 2017). Satellite-based fire emission estimates are available globally but cover only the present-day period, i.e., since 1997 for the Global Fire Emissions Dataset (GFED) and shorter periods for others.

Historical change in fire emissions has been inferred from a variety of proxies, such as ice-core records of $\mathrm{CH}_{4}$ (isotope $\delta^{13} \mathrm{CH}_{4}$ from a pyrogenic or biomass burning source), black carbon, levoglucosan, vanillic acid, ammonium, and CO (Ferretti et al., 2005; McCornnell et al., 2007; Conedera et al., 2009; Wang et al., 2012; Zennaro et al., 2014), site-level sedimentary charcoal records (Marlon et al., 2008, 2016), visibility records (van Marle et al., 2017a), and firescar records (Falk et al., 2011). Fire proxies can be used to reconstruct fire emissions on a local to global scale and for time periods of decades to millennia and beyond. However, they are of limited spatial extent and cannot be directly converted into emission amounts. Moreover, large uncertainties and discrepancies were shown in their inferred regional or global long-term trends due to limited sample size and often 
Table 1. Summary description of the dynamic global vegetation models (DGVMs) that participated in FireMIP.

\begin{tabular}{|c|c|c|c|c|c|c|}
\hline DGVMs & $\begin{array}{l}\text { tem. res. } \\
\text { of model } \\
\text { outputs }\end{array}$ & $\begin{array}{l}\text { spatial res. } \\
\text { of model } \\
\text { outputs }\end{array}$ & period & $\begin{array}{l}\text { natural } \\
\text { veg. } \\
\text { distrib. }\end{array}$ & fire scheme ref. & DGVM ref. \\
\hline $\begin{array}{l}\text { CLM4.5 but CLM5 fire } \\
\text { model (CLM4.5) }\end{array}$ & monthly & $\begin{array}{l}\sim 1.9^{\circ} \text { (lat) } \\
\times 2.5^{\circ} \text { (lon) }\end{array}$ & 1700-2012 & $\mathrm{P}$ & $\begin{array}{l}\mathrm{Li} \text { et al. }(2012,2013) \\
\mathrm{Li} \text { and Lawrence (2017) }\end{array}$ & Oleson et al. (2013) \\
\hline CTEM & monthly & $2.8125^{\circ}$ & $1861-2012$ & $\mathrm{P}$ & $\begin{array}{l}\text { Arora and Boer (2005) } \\
\text { Melton and Arora (2016) }\end{array}$ & Melton and Arora (2016) \\
\hline $\begin{array}{l}\text { JSBACH-SPITFIRE } \\
(\text { JSBACH })\end{array}$ & monthly & $1.875^{\circ}$ & 1700-2012 & $\mathrm{P}$ & $\begin{array}{l}\text { Lasslop et al. (2014) } \\
\text { Thonicke et al. (2010) }\end{array}$ & Brovkin et al. (2013) \\
\hline $\begin{array}{l}\text { JULES-INFERNO } \\
\text { (JULES) }\end{array}$ & monthly & $\begin{array}{l}\sim 1.2^{\circ} \text { (lat) } \\
\times 1.9^{\circ} \text { (lon) }\end{array}$ & 1700-2012 & M & Mangeon et al. (2016) & $\begin{array}{l}\text { Best et al. (2011) } \\
\text { Clark et al. (2011) }\end{array}$ \\
\hline $\begin{array}{l}\text { LPJ-GUESS-GlobFIRM } \\
\text { (LGG) }\end{array}$ & annual & $0.5^{\circ}$ & 1700-2012 & M & Thonicke et al. (2001) & $\begin{array}{l}\text { Smith et al. (2014) } \\
\text { Lindeskog et al. (2013) }\end{array}$ \\
\hline $\begin{array}{l}\text { LPJ-GUESS-SPITFIRE } \\
\text { (LGS) }\end{array}$ & monthly & $0.5^{\circ}$ & 1700-2012 & M & $\begin{array}{l}\text { Lehsten et al. (2009) } \\
\text { Rabin et al. (2017) }\end{array}$ & $\begin{array}{l}\text { Smith et al. (2001) } \\
\text { Ahlström et al. (2012) }\end{array}$ \\
\hline $\begin{array}{l}\text { LPJ-GUESS-SIMFIRE } \\
\text {-BLAZE (LGSB) }\end{array}$ & monthly & $0.5^{\circ}$ & 1700-2012 & M & Knorr et al. (2016) & $\begin{array}{l}\text { Smith et al. (2014) } \\
\text { Lindeskog et al. (2013) }\end{array}$ \\
\hline MC2 & annual & $0.5^{\circ}$ & 1901-2008 & M & $\begin{array}{l}\text { Bachelet et al. (2015) } \\
\text { Sheehan et al. (2015) }\end{array}$ & $\begin{array}{l}\text { Bachelet et al. (2015) } \\
\text { Sheehan et al. (2015) }\end{array}$ \\
\hline $\begin{array}{l}\text { ORCHIDEE-SPITFIRE } \\
\text { (ORCHIDEE) }\end{array}$ & monthly & $0.5^{\circ}$ & 1700-2012 & $P$ & $\begin{array}{l}\text { Yue et al. }(2014,2015) \\
\text { Thonicke et al. }(2010)\end{array}$ & Krinner et al. (2005) \\
\hline
\end{tabular}

Abbreviations: CLM4.5 and CLM5: Community Land Model version 4.5 and 5; CTEM: Canadian Terrestrial Ecosystem Model; JSBACH: Jena Scheme for BiosphereAtmosphere Coupling in Hamburg; SPITFIRE: Spread and InTensity fire model; JULES: Joint UK Land Environment Simulator; INFERNO: Interactive Fire And Emission Algorithm For Natural Environments; GlobFIRM: fire module Global FIRe Model; SMIFIRE: SIMple FIRE model; BLAZE: Blaze-Induced Land-Atmosphere Flux Estimator; ORCHIDEE: Organizing Carbon Hydrology In Dynamic Ecosystems; PFT: plant functional type; P: prescribed; M: modeled.

unclear representative areas and time periods of fire emissions (Pechony and Shindell, 2010; van der Werf et al., 2013; Legrand et al., 2016).

Dynamic global vegetation models (DGVMs) that include fire modeling are indispensable for estimating fire carbon emissions at local to global scales for past, present, and future periods (Hantson et al., 2016). These models represent interactions among fire dynamics, biogeochemistry, biogeophysics, and vegetation dynamics at the land surface within a physically and chemically consistent modeling framework. DGVMs are often used as the terrestrial ecosystem component of Earth system models (ESMs) and have been widely applied in global change research (Levis et al., 2004; Li et al., 2013; Kloster and Lasslop, 2017). Fire emissions of trace gases and aerosols can be derived from the product of fire carbon emissions simulated by DGVMs and fire emission factors (Li et al., 2012; Knorr et al., 2016).

Modeling fire and fire emissions within DGVMs started in the early 2000s (Thonicke et al., 2001) and has rapidly progressed during the past decade (Hantson et al., 2016). The Fire Model Intercomparison Project (FireMIP) initiated in 2014 was the first international collaborative effort to better understand the behavior of global fire models (Hantson et al., 2016). A set of common fire modeling experiments driven by the same forcing data were performed (Rabin et al., 2017). Nine DGVMs with different state-of-the-art global fire models participated in FireMIP. All global fire models used in the upcoming 6th Coupled Model Intercomparison Project
(CMIP6) and IPCC AR6 are included in FireMIP, except for the fire scheme in GFDL-ESM (Rabin et al., 2018; Ward et al., 2018), which is similar to that of CLM4.5 (Li et al., 2012) in FireMIP. Note that GlobFIRM (Thonicke et al., 2001) in FireMIP is the most commonly used fire scheme in CMIP5 (Kloster and Lasslop, 2017) and is still used by some models in CMIP6.

Earlier studies provided only one single time series of fire emissions for global grids or regions (Schultz et al., 2008; Mieville et al., 2010; Lamarque et al., 2010; Marlon et al., 2016; van Marle et al., 2017b; and references therein). This limits their utility for quantifying the uncertainties in global and regional reconstructions of fire emissions and the corresponding impacts on estimated historical changes in carbon cycle, climate, and air pollution. A small number of studies also investigated the drivers of fire carbon emission trends (Kloster et al., 2010; Yang et al., 2014; Li et al., 2018; Ward et al., 2018). However, these studies could not identify the uncertainty source in recent model-based reconstructions or help understand the inter-model discrepancy in projections of future fire emissions because only a single DGVM was used in each.

This study provides a new dataset of global gridded fire emissions, including carbon and 33 species of trace gases and aerosols, over the 1700-2012 time period, based on nine DGVMs with different state-of-the-art global fire models that participated in FireMIP. The dataset provides a basis for developing multi-source (e.g., satellite-based products, model 
simulations, and/or fire proxy records) merged fire emission reconstructions and methods. It also, for the first time, allows end users to select all or a subset of model-based reconstructions that best suit their regional or global research needs. Importantly, it enables the quantification of the uncertainty range of past fire emissions and their impacts. In addition, the model-based estimates of fire emissions are comprehensively evaluated through comparison with satellite-based products, including amounts, spatial distribution, seasonality, and interannual variability, thus providing information on the limitations of recent model-based reconstructions. We also analyze the simulated long-term changes and the drivers for each DGVM and inter-model differences.

\section{Methods and datasets}

\subsection{Models in FireMIP}

Nine DGVMs with different fire modules participated in FireMIP: CLM4.5 with the CLM5 fire module, CTEM, JSBACH-SPITFIRE, JULES-INFERNO, LPJ-GUESSGlobFIRM, LPJ-GUESS-SIMFIRE-BLAZE, LPJ-GUESSSPITFIRE, MC2, and ORCHIDEE-SPITFIRE (Table 1; see Rabin et al., 2017, for a detailed description of each model). JSBACH, ORCHIDEE, and LPJ-GUESS used the variants of SPITFIRE (Thonicke et al., 2010) with updated representation of human ignition and suppression, fuel moisture, combustion completeness, and the relationship between spread rate and wind speed for JSBACH (Lasslop et al., 2014), combustion completeness for ORCHIDEE (Yue et al., 2014, 2015), and human ignition, post-fire mortality factors, and modifications for matching tree age/size structure for LPJ-GUESS (Lehsten et al., 2009; Rabin et al., 2017).

The global fire models in the nine DGVMs have diverse levels of complexity (Rabin et al., 2017). SIMFIRE is a statistical model based on present-day satellite-based fire products (Knorr et al., 2016). In CLM4.5, crop, peat, and tropical deforestation fires are empirically/statistically modeled (Li et al., 2013). The scheme for fires outside the tropical closed forests and croplands in CLM4.5 (Li et al., 2012; $\mathrm{Li}$ and Lawrence, 2017), fire modules in CTEM (Arora and Boer, 2005; Melton and Arora, 2016), GlobFIRM (Thonicke, 2001), and INFERNO (Mangeon et al., 2016) are processbased and of intermediate complexity. That is, area burned is determined by two processes: fire occurrence and fire spread, but with simple empirical/statistical equations for each process. Fire modules in MC2 (Bachelet et al., 2015; Sheehan et al., 2015) and SPITFIRE variants are more complex, which use the Rothermel equations (Rothermel, 1972) to model fire spread and consider the impact of fuel composition on fire behavior.

How humans affect fires differs among these global fire models (Table 2), which influences their estimates of fire emissions. GlobFIRM does not consider any direct human effect on fires and the MC2 fire model only considers human suppression on fire. CLM4.5 models fires in croplands, human deforestation and degradation fires in tropical closed forests, and human ignition and suppression for both occurrence and spread of fires outside of tropical closed forests and croplands. Burned area in SIMFIRE and human influence on fire occurrence in other models are a nonlinear function of population density. CTEM and JSBACHSPITFIRE also consider human suppression on fire duration. JULES-INFERNO treats croplands and crop fires as natural grasslands and grassland fires. All models, except for CLM4.5 and INFERNO, set burned area to zero in croplands. FireMIP models treat pasture fires as natural grassland fires by using the same parameter values if they have pasture plant functional types (PFTs) or lumping pastures with natural grasslands otherwise. Biomass harvest is considered in pastures in LPJ-GUESS-GlobFIRM and LPJGUESS-SIMFIRE-BLAZE, which decreases fuel availability for fires, and that JSBACH-SPITFIRE sets high fuel bulk density for pasture PFTs.

Only CLM4.5 simulates peat fires, although only emissions from burning of vegetation tissues and litter are included in outputs for FireMIP; i.e., burning of soil organic matter is not included (Table 2).

In the FireMIP models, fire carbon emissions are calculated as the product of burned area, fuel load, and combustion completeness. Combustion completeness is the fraction of live plant tissues and ground litter burned (0\%-100\%). It depends on PFT and plant tissue type in GlobFIRM and in the fire modules of CLM4.5 and CTEM, and is also a function of soil moisture in INFERNO. Combustion completeness depends on plant tissue type and surface fire intensity in SIMFIRE, fuel type and wetness in the SPITFIRE family models, and fuel type, load, and moisture in the MC2 fire module.

\subsection{FireMIP experimental protocol and input datasets}

The nine DGVMs in FireMIP are driven with the same forcing data (Rabin et al., 2017). The atmospheric forcing is from CRU-NCEP v5.3.2 with a spatial resolution of $0.5^{\circ}$ and a 6-hourly temporal resolution (Wei et al., 2014). The 1750-2012 annual global atmospheric $\mathrm{CO}_{2}$ concentration is derived from ice-core and NOAA monitoring station data (Le Quéré et al., 2014). Annual land use and land cover change (LULCC) and population density at a $0.5^{\circ}$ resolution for 1700-2012 are from Hurtt et al. (2011) and Klein Goldewijk et al. (2010, HYDE v3.1), respectively. Monthly cloud-to-ground lightning frequency for 1901-2012, at $0.5^{\circ}$ resolution, is derived from the observed relationship between present-day lightning and convective available potential energy (CAPE) anomalies (Pfeiffer et al., 2013; Jed O. Kaplan, personal communication, 2015). Fire emissions in this study are estimated using the model outputs of PFT-level fire carbon emissions and vegetation characteristics (PFTs and their 
Table 2. Summary description of global fire modules in FireMIP DGVMs.

\begin{tabular}{|c|c|c|c|c|c|c|c|}
\hline DGVMs & $\begin{array}{l}\text { crop } \\
\text { fire }\end{array}$ & $\begin{array}{l}\text { tropical } \\
\text { human } \\
\text { defor. fire }\end{array}$ & $\begin{array}{l}\text { human } \\
\text { ignition }\end{array}$ & $\begin{array}{l}\text { human fire } \\
\text { suppression }\end{array}$ & $\begin{array}{l}\text { peat } \\
\text { fire }\end{array}$ & pasture & $\begin{array}{l}\text { combust. } \\
\text { complete. range } \\
\text { of woody tissue }\end{array}$ \\
\hline CLM4.5 & yes & yes & $\begin{array}{l}\text { increase } \\
\text { with } \mathrm{PD}^{\mathrm{a}}\end{array}$ & $\begin{array}{l}\text { occurrence \& } \\
\text { spread area }^{b}\end{array}$ & yes $^{\mathrm{e}}$ & $\begin{array}{l}\text { as natural } \\
\text { grassland }\end{array}$ & $\begin{array}{l}27 \%-35 \%(\text { stem }) \\
40 \%\left(\mathrm{CWD}^{\mathrm{f}}\right)\end{array}$ \\
\hline CTEM & no & no & $\begin{array}{l}\text { increase } \\
\text { with PD }\end{array}$ & $\begin{array}{l}\text { occurrence \& } \\
\text { duration }\end{array}$ & no & $\begin{array}{l}\text { as natural } \\
\text { grassland }\end{array}$ & $\begin{array}{l}6 \% \text { (stem) } \\
15 \%-18 \%(\mathrm{CWD})\end{array}$ \\
\hline JSBACH & $\begin{array}{l}\text { as grass } \\
\text { fire }\end{array}$ & no & $\begin{array}{l}\text { increase } \\
\text { with PD }\end{array}$ & $\begin{array}{l}\text { occurrence \& } \\
\text { duration }\end{array}$ & no & $\begin{array}{l}\text { high fuel } \\
\text { bulk den. }\end{array}$ & $0 \%-45 \%$ \\
\hline JULES & no & no & $\begin{array}{l}\text { increase } \\
\text { with PD }\end{array}$ & occurrence $^{c}$ & no & $\begin{array}{l}\text { as natural } \\
\text { grassland }\end{array}$ & $0 \%-40 \%$ \\
\hline LGG & no & no & no & no & no & harvest & $70 \%-90 \%$ \\
\hline LGS & no & no & $\begin{array}{l}\text { increase } \\
\text { with PD }\end{array}$ & occurrence $^{c}$ & no & $\begin{array}{l}\text { as natural } \\
\text { grassland }\end{array}$ & $\begin{array}{l}0 \%-98 \%\left(100 \mathrm{~h}^{\mathrm{g}}\right) \\
0 \%-80 \%\left(1000 \mathrm{~h}^{\mathrm{g}}\right)\end{array}$ \\
\hline LGSB & no & no & $\begin{array}{l}\text { increase } \\
\text { with PD }\end{array}$ & burned area & no & harvest & $0 \%-50 \%$ \\
\hline MC2 & no & no & no & occurrence $^{\mathrm{d}}$ & no & $\begin{array}{l}\text { as natural } \\
\text { grassland }\end{array}$ & $\begin{array}{l}0 \%-87 \%(100 \mathrm{~h}) \\
0 \%-43 \%(1000 \mathrm{~h})\end{array}$ \\
\hline ORCHIDEE & no & no & $\begin{array}{l}\text { increase } \\
\text { with PD }\end{array}$ & occurrence $^{\mathrm{c}}$ & no & $\begin{array}{l}\text { as natural } \\
\text { grassland }\end{array}$ & $\begin{array}{l}0 \%-73 \%(100 \mathrm{~h}) \\
0 \%-41 \%(1000 \mathrm{~h})\end{array}$ \\
\hline
\end{tabular}

a PD: population density. ${ }^{\mathrm{b}}$ Fire suppression increases with PD and GDP, different between tree PFTs and grass/shrub PFTs. ${ }^{\mathrm{c}}$ Fire suppression increases with PD. ${ }^{\mathrm{d}}$ Assume no fire in grid cell when pre-calculated rate of spread, fireline intensity, and energy release component are lower than thresholds. ${ }^{\mathrm{e}}$ CLM4.5 outputs in FireMIP include biomass and litter burning due to peat fires, but do not include burning of soil organic matter. ${ }_{\mathrm{f}}$ Coarse woody debris. $\mathrm{g} 100 \mathrm{~h}$ fuels and $1000 \mathrm{~h}$ fuel classes.

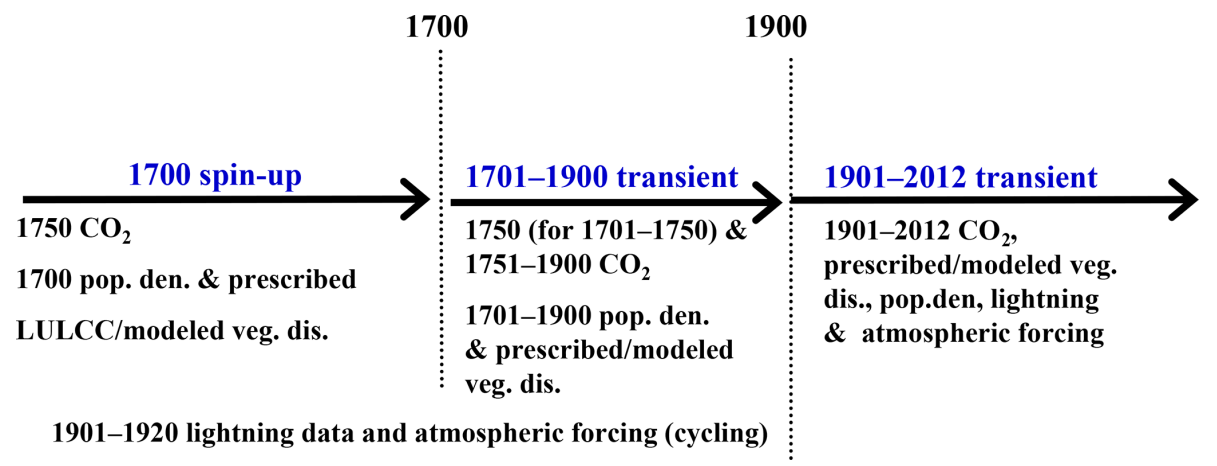

Figure 1. FireMIP experiment design. Note that CTEM and MC2 start at 1861 and 1901 and spin-up using 1861 and $1901 \mathrm{CO}_{2}$, population density, and prescribed/modeled vegetation distribution, respectively.

fractional area coverages) from the FireMIP historical transient control run (SF1) (Rabin et al., 2017). SF1 includes three phases (Fig. 1): the 1700 spin-up phase, the 1701-1900 transient phase, and the 1901-2012 transient phase. In the 1700 spin-up phase, all models are spun up to equilibrium, forced by population density and prescribed LULCC at their 1700 values, 1750 atmospheric $\mathrm{CO}_{2}$ concentration, and the repeatedly cycled 1901-1920 atmospheric forcing (precipitation, temperature, specific humidity, surface pressure, wind speed, and solar radiation) and lightning data. The 17011900 transient phase is forced by 1701-1900 time-varying population and LULCC, with constant $\mathrm{CO}_{2}$ concentration at 1750 level until 1750 and time-varying $\mathrm{CO}_{2}$ concentration for 1750-1900, and the cycled 1901-1920 atmospheric forcing and lightning data. In the 1901-2012 transient phase, models are driven by 1901-2012 time-varying population density, LULCC, $\mathrm{CO}_{2}$ concentration, atmospheric forcing, and lightning data. Unlike all other models, MC2 and CTEM run from 1901 and 1861, respectively, rather than 1700.

Six FireMIP models (CLM4.5, JSBACH-SPITFIRE, JULES-INFERNO, LPJ-GUESS-SPITFIRE, LPJ-GUESSSIMFIRE-BLAZE, and ORCHIDEE-SPITFIRE) also provide outputs of five sensitivity simulations: constant climate, constant atmospheric $\mathrm{CO}_{2}$ concentration, constant land cover, constant population density, and constant lightning frequency throughout the whole simulation period. The sen- 
sitivity simulations are helpful for understanding the drivers of changes in reconstructed fire emissions.

\subsection{Estimates of fire trace gas and aerosol emissions}

Based on fire carbon emissions and vegetation characteristics from DGVMs and fire emission factors, fire emissions of trace gas and aerosol species $i$ and the PFT $j, E_{i, j}$ (g species $\mathrm{m}^{-2} \mathrm{~s}^{-1}$ ) are estimated according to Andreae and Merlet (2001):

$E_{i, j}=\mathrm{EF}_{i, j} \times \mathrm{CE}_{j} /[C]$,

where $\mathrm{EF}_{i, j}\left(\mathrm{~g}\right.$ species $(\mathrm{kg} \text { dry matter }(\mathrm{DM}))^{-1}$ ) is a PFTspecific emission factor $(\mathrm{EF}), \mathrm{CE}_{j}$ denotes the fire carbon emissions of PFT $j\left(\mathrm{~g} \mathrm{C} \mathrm{m}^{-2} \mathrm{~s}^{-1}\right)$, and $[C]=0.5 \times 10^{3} \mathrm{gC}$ $(\mathrm{kg} \mathrm{DM})^{-1}$ is a unit conversion factor from carbon to dry matter.

The EFs used in this study (Table 3) are based on Andreae and Merlet (2001), with updates from field and laboratory studies over various land cover types published during 20012018 (Andreae, 2019). All FireMIP model simulations used the same EFs from Table 3.

DGVMs generally simulate vegetation as a mixture of PFTs in a given grid location to represent plant function at global scale, instead of land cover types. In Table 4, we associate the PFTs from each DGVM with the land cover types shown in Table 3. Grass, shrub, savannas, woodland, pasture, and tundra PFTs are classified as grassland/savannas. Tree PFTs and crop PFTs are classified as forests and croplands, respectively, similarly to Li et al. (2012), Mangeon et al. (2016), and Melton and Arora (2016). PFTs of evergreen and other broadleaf deciduous tree in CTEM, extra-tropical evergreen and deciduous tree in JSBACH, and broadleaf deciduous tree and needleleaf evergreen tree in JULES are divided into tropical, temperate, and boreal groups following Nemani and Running (1996).

We provide two versions of fire emission products with different spatial resolutions: the original spatial resolution for each FireMIP DGVM output (Table 1 ) and a $1 \times 1^{\circ}$ horizontal resolution. For the latter, fire emissions are unified to $1^{\circ}$ resolution using bilinear interpolation for CLM4.5, CTEM, JSBACH, and JULES, which have coarser resolution, and area-weighted averaging-up for other models whose original resolution is $0.5^{\circ}$. The $1 \times 1^{\circ}$ product is used for present-day evaluation and historical trend analyses in Sects. 3 and 4.

\subsection{Benchmarks}

Satellite-based products are commonly used as benchmarks to evaluate present-day fire emission simulations (Rabin et al., 2017, and references therein). In the present study, six satellite-based products are used (Table 5). Fire emissions in GFED4/GFED4s (small fires included in GFED4s) (van der Werf et al., 2017), GFAS1.2 (Kaiser et al., 2012) and FINN1.5 (Wiedinmyer et al., 2011) are based on emission factor (EF) and fire carbon emission (CE) (Eq. 1). CE is estimated from MODIS burned area and VIRS/ATSR active fire products in the GFED family, MODIS active fire detection in FINN1.5, and MODIS fire radiative power (FRP) in GFAS1. Fire emissions from FEER1 (Ichoku and Ellison, 2014) and QFEDv2.5 (Darmenov and da Silva, 2015) are derived using FRP and constrained with satellite AOD observations. Satellite-based present-day fire emissions for the same region can differ by a factor of 2-4 on an annual basis (van der Werf et al., 2010) and up to 12 on a monthly basis (Zhang et al., 2014). The discrepancy among satellite-based estimates of present-day fire emissions mainly comes from the satellite observations used, the methods applied for deriving fire emissions, and the emission factors.

\subsection{Multi-source merged historical reconstructions}

We also compared the simulated historical changes with historical reconstructions merged from multiple sources used as forcing data for CMIPs. Fire emission estimates for CMIP5 and CMIP6 were merged from different sources (Table 5). For CMIP5 (Lamarque et al., 2010), the decadal fire emissions are available from 1850 to 2000 , estimated using GFED2 fire emissions (van der Werf et al., 2006) for 1997 onwards, RETRO (Schultz et al., 2008) for 1960-1900, and GICC (Mieville et al., 2010) for 1900-1950, and kept constant at the 1900 level for 1850-1900. RETRO combined literature reviews with satellite-based fire products and the GlobFIRM fire model. GICC is based on a burned area reconstruction from literature review and sparse tree ring records (Mouillot and Field, 2005), satellite-based fire counts, land cover map, and representative biomass density and burning efficiency of each land cover type.

For CMIP6, monthly fire emission estimates are available from 1750 to 2015 (van Marle et al., 2017b). The CMIP6 estimates are merged from GFED4s fire carbon emissions for 1997 onwards, charcoal records GCDv3 (Marlon et al., 2016) for North America and Europe, visibility records for equatorial Asia (Field et al., 2009) and the central Amazon (van Marle et al., 2017b), and the median of simulations of six FireMIP models (CLM4.5, JSBACH-SPITFIRE, JULES-INFERNO, LPJ-GUESS-SPITFIRE, LPJ-GUESSSIMFIRE-BLAZE, and ORCHIDEE-SPITFIRE) for all other regions. Then, based on the merged fire carbon emissions, CMIP6 fire trace gas and aerosol emissions are derived using EF from Andreae and Merlet (2001) with updates to 2013 and Akagi et al. (2011) with updates for temperate forests to 2014, and a present-day land cover map.

\section{Evaluation of present-day fire emissions}

The spatial pattern and temporal variability of different fire emission species are similar, with some slight differences resulting from the estimated fire carbon emissions from the 
Table 3. Emission factors (g species $(\mathrm{kg} \mathrm{DM})^{-1}$ ) for land cover types (LCTs).

\begin{tabular}{|c|c|c|c|c|c|c|}
\hline No. & Species & Grassland/savanna & Tropical forest & Temperate forest & Boreal forest & Cropland \\
\hline 1 & $\mathrm{CO}_{2}$ & 1647 & 1613 & 1566 & 1549 & 1421 \\
\hline 2 & $\mathrm{CO}$ & 70 & 108 & 112 & 124 & 78 \\
\hline 3 & $\mathrm{CH}_{4}$ & 2.5 & 6.3 & 5.8 & 5.1 & 5.9 \\
\hline 4 & NMHC & 5.5 & 7.1 & 14.6 & 5.3 & 5.8 \\
\hline 5 & $\mathrm{H}_{2}$ & 0.97 & 3.11 & 2.09 & 1.66 & 2.65 \\
\hline 6 & $\mathrm{NO}_{x}$ & 2.58 & 2.55 & 2.90 & 1.69 & 2.67 \\
\hline 7 & $\mathrm{~N}_{2} \mathrm{O}$ & 0.18 & 0.20 & 0.25 & 0.25 & 0.09 \\
\hline 8 & $\mathrm{PM}_{2.5}$ & 7.5 & 8.3 & 18.1 & 20.2 & 8.5 \\
\hline 9 & ТРМ & 8.5 & 10.9 & 18.1 & 15.3 & 11.3 \\
\hline 10 & TPC & 3.4 & 6.0 & 8.4 & 10.6 & 5.5 \\
\hline 11 & $\mathrm{OC}$ & 3.1 & 4.5 & 8.9 & 10.1 & 5.0 \\
\hline 12 & $\mathrm{BC}$ & 0.51 & 0.49 & 0.66 & 0.50 & 0.43 \\
\hline 13 & $\mathrm{SO}_{2}$ & 0.51 & 0.78 & 0.75 & 0.75 & 0.81 \\
\hline 14 & $\mathrm{C}_{2} \mathrm{H}_{6}$ (ethane) & 0.42 & 0.94 & 0.71 & 0.90 & 0.76 \\
\hline 15 & $\mathrm{CH}_{3} \mathrm{OH}$ (methanol) & 1.48 & 3.15 & 2.13 & 1.53 & 2.63 \\
\hline 16 & $\mathrm{C}_{3} \mathrm{H}_{8}$ (propane) & 0.14 & 0.53 & 0.29 & 0.28 & 0.20 \\
\hline 17 & $\mathrm{C}_{2} \mathrm{H}_{2}$ (acetylene) & 0.34 & 0.43 & 0.35 & 0.27 & 0.32 \\
\hline 18 & $\mathrm{C}_{2} \mathrm{H}_{4}$ (ethylene) & 1.01 & 1.11 & 1.22 & 1.49 & 1.14 \\
\hline 19 & $\mathrm{C}_{3} \mathrm{H}_{6}$ (propylene) & 0.49 & 0.86 & 0.67 & 0.66 & 0.48 \\
\hline 20 & $\mathrm{C}_{5} \mathrm{H}_{8}$ (isoprene) & 0.12 & 0.22 & 0.19 & 0.07 & 0.18 \\
\hline 21 & $\mathrm{C}_{10} \mathrm{H}_{16}$ (terpenes) & 0.10 & 0.15 & 1.07 & 1.53 & 0.03 \\
\hline 22 & $\mathrm{C}_{7} \mathrm{H}_{8}$ (toluene) & 0.20 & 0.23 & 0.43 & 0.32 & 0.18 \\
\hline 23 & $\mathrm{C}_{6} \mathrm{H}_{6}$ (benzene) & 0.34 & 0.38 & 0.46 & 0.52 & 0.31 \\
\hline 24 & $\mathrm{C}_{8} \mathrm{H}_{10}$ (xylene) & 0.09 & 0.09 & 0.17 & 0.10 & 0.09 \\
\hline 25 & $\mathrm{CH}_{2} \mathrm{O}$ (formaldehyde) & 1.33 & 2.40 & 2.22 & 1.76 & 1.80 \\
\hline 26 & $\mathrm{C}_{2} \mathrm{H}_{4} \mathrm{O}$ (acetaldehyde) & 0.86 & 2.26 & 1.20 & 0.78 & 1.82 \\
\hline 27 & $\mathrm{C}_{3} \mathrm{H}_{6} \mathrm{O}$ (acetone) & 0.47 & 0.63 & 0.70 & 0.61 & 0.61 \\
\hline 28 & $\mathrm{C}_{3} \mathrm{H}_{6} \mathrm{O}_{2}$ (hydroxyacetone) & 0.52 & 1.13 & 0.85 & 1.48 & 1.74 \\
\hline 29 & $\mathrm{C}_{6} \mathrm{H}_{5} \mathrm{OH}$ (phenol) & 0.37 & 0.23 & 0.33 & 2.96 & 0.50 \\
\hline 30 & $\mathrm{NH}_{3}$ (ammonia) & 0.91 & 1.45 & 1.00 & 2.82 & 1.04 \\
\hline 31 & HCN (hydrogen cyanide) & 0.42 & 0.38 & 0.62 & 0.81 & 0.43 \\
\hline 32 & MEK/2-butanone & 0.13 & 0.50 & 0.23 & 0.15 & 0.60 \\
\hline 33 & $\mathrm{CH}_{3} \mathrm{CN}$ (acetonitrile) & 0.17 & 0.51 & 0.23 & 0.30 & 0.25 \\
\hline
\end{tabular}

land cover types that have different emission factors (Table 3). Therefore, we focus on several important species as examples to exhibit the performance of FireMIP models in the simulations of present-day fire emissions.

\subsection{Global amounts and spatial distributions}

As shown in Table 6, FireMIP models, except for MC2 and LPJ-GUESS-GlobFIRM, estimate present-day fire carbon, $\mathrm{CO}_{2}, \mathrm{CO}, \mathrm{CH}_{4}, \mathrm{BC}, \mathrm{OC}$, and $\mathrm{PM}_{2.5}$ annual emissions to be within the range of satellite-based products. For example, the estimated range of fire carbon emissions is 1.73.0 $\mathrm{Pg} \mathrm{Cyr}^{-1}$, whereas it is $1.5-4.2 \mathrm{PgC} \mathrm{yr}^{-1}$ for satellitebased products. Low fire emissions in MC2 result from relatively low simulated global burned area, only about $1 / 4$ of satellite-based observations (Andela et al., 2017). In contrast, high emissions in LPJ-GUESS-GlobFIRM are mainly due to the higher combustion completeness of woody tissues (70 \%-90\% of stem and coarse woody debris burned in post- fire regions) than those used in other FireMIP models (Table 2) and the satellite-based GFED family (20\%-40\% for stem and $40 \%-60 \%$ for coarse woody debris) (van der Werf et al., 2017).

FireMIP DGVMs, except for MC2, represent the general spatial distribution of fire emissions evident in satellite-based products, with high fire BC emissions over tropical savannas and low emissions over the arid and sparsely vegetated regions (Fig. 2). Among the nine models, CLM4.5, JULESINFERNO, and LPJ-GUESS-SIMFIRE-BLAZE have higher global spatial pattern correlation with satellite-based products than the other models, indicating higher skill in their spatial-pattern simulations. It should also be noted that, on a regional scale, CTEM, JULES-INFERNO, LPJ-GUESSSPITFIRE, and ORCHIDEE-SPITFIRE underestimate fire emissions over boreal forests in Asia and North America. LPJ-GUESS-GlobFIRM and LPJ-GUESS-SIMFIREBLAZE overestimate fire emissions over the Amazon and 
Table 4. Attribution of plant function types (PFTs) in FireMIP DGVMs to land cover types (LCTs) for emission factors described in Table 2.

\begin{tabular}{|c|c|c|c|c|c|}
\hline $\begin{array}{l}\text { LCT } \\
\text { models }\end{array}$ & $\begin{array}{l}\text { Grassland/ } \\
\text { savannas }\end{array}$ & $\begin{array}{l}\text { Tropical } \\
\text { forest }\end{array}$ & $\begin{array}{l}\text { Temperate } \\
\text { forest }\end{array}$ & $\begin{array}{l}\text { Boreal } \\
\text { forest }\end{array}$ & Cropland \\
\hline \multirow[t]{4}{*}{ CLM4.5 } & $\mathrm{A} \mathrm{C} 3 / \mathrm{C} 3 / \mathrm{C} 4 \mathrm{G}$ & Tro BE T & Tem NE T & Bor NE T & Crop \\
\hline & Bor BD S & Tro BD T & Tem BE T & Bor ND T & \\
\hline & Tem BE/BD S & Tro BD T & Tem BE T & Bor ND T & \\
\hline & & & Tem BD T & Bor BD T & \\
\hline \multirow[t]{2}{*}{ CTEM } & $\mathrm{C} 3 / \mathrm{C} 4 \mathrm{G}$ & $\mathrm{BE} \mathrm{T}^{\mathrm{a}}$ & $\mathrm{NE} / \mathrm{BE} \mathrm{T}^{\mathrm{a}}$ & $\mathrm{NET}^{\mathrm{a}}$ & C3/C4 crop \\
\hline & & Other BD $\mathrm{T}^{\mathrm{a}}$ & Other BD $\mathrm{T}^{\mathrm{a}}$ & Cold BD T & \\
\hline JSBACH & $\mathrm{C} 3 / \mathrm{C} 4 \mathrm{G} / \mathrm{P}$ & Tro E/D T & Ex-Tro E/D T ${ }^{\mathrm{a}}$ & Ex-Tro E/D T ${ }^{\mathrm{a}}$ & Crop \\
\hline \multirow[t]{2}{*}{ JULES } & $\mathrm{C} 3 / \mathrm{C} 4 \mathrm{G}$ & Tro BE T & Tem BE T & $\mathrm{BD} / \mathrm{NE} \mathrm{T}^{\mathrm{a}}$ & \\
\hline & $\mathrm{E} / \mathrm{D} \mathrm{S}$ & $\mathrm{BD} \mathrm{T}^{\mathrm{a}}$ & $\mathrm{BD} / \mathrm{NE} \mathrm{T}^{\mathrm{a}}$ & NDT & \\
\hline \multirow[t]{2}{*}{$\mathrm{LGG}^{\mathrm{b}}$} & $\mathrm{C} 3 / \mathrm{C} 4 \mathrm{G}$ & Tro BE/BR T & Tem NSG/BSG/BE T & Bor NE T & R/I S/W wheat \\
\hline & $\mathrm{C} 3 / \mathrm{C} 4 \mathrm{G}$ in $\mathrm{P}$ & Tro SI BE T & Tem SI SG B T & Bor SI NE T & $\mathrm{R} / \mathrm{I}$ maize \\
\hline \multirow[t]{2}{*}{ LGS } & $\mathrm{C} 3 / \mathrm{C} 4 \mathrm{G}$ & Tro BE/BR T & Tem SI/\&SG B T & Bor NE T & \\
\hline & & Tro SI BE T & Tem B/N E T & Bor SI/\&SG NE/N T & \\
\hline \multirow[t]{2}{*}{$\operatorname{LGSB}^{\mathrm{b}}$} & $\mathrm{C} 3 / \mathrm{C} 4 \mathrm{G}$ & Tro BE/BR T & Tem NSG/BSG/ BE T & Bor NE T & R/I S/W wheat \\
\hline & $\mathrm{C} 3 / \mathrm{C} 4 \mathrm{G}$ in $\mathrm{P}$ & Tro SI BE T & Tem SI SG B T & Bor SI NE T & $\mathrm{R} / \mathrm{I}$ maize \\
\hline \multirow[t]{7}{*}{ MC2 } & Tem C3 G/S & Tro BE T & Maritime NE F & Bor NE F & \\
\hline & Sub-Tro C4 G/S & Tro $\mathrm{D} \mathrm{W}^{\mathrm{c}}$ & Sub-Tro NE/BD/BE/M F & Subalpine F & \\
\hline & Tro S/G/Sava & & Tem NE/BD F & Cool N F & \\
\hline & Bor M W & & Tem C/W M F & & \\
\hline & Tem/Sub-Tro NE/B/M W & & & & \\
\hline & Tundra & & & & \\
\hline & Taiga-tundra & & & & \\
\hline \multirow[t]{2}{*}{ ORCHIDEE } & $\mathrm{C} 3 / \mathrm{C} 4 \mathrm{G}$ & Tro B E/R T & Tem N/B E T & Bor N E/D T & $\mathrm{C} 3 / \mathrm{C} 4$ crop \\
\hline & & & Tem BD T & Bor BT T & \\
\hline
\end{tabular}

Abbreviations: T: tree; S: shrub; W: woodland; F: forest; G: grass; P: pasture; Sava: savanna; N: needleleaf; E: evergreen; B: broadleaf; D: deciduous; R: rain-green; SI: shaded-intolerant; SG: summer-green; M: mixed; I: irrigated; RF: rainfed; C/W: cool or warm; S/W: spring or winter, Tro: tropical; Tem: temperate; Bor: boreal; Sub-Tro: subtropical; Ex-Tro: extratropical; A: Arctic. ${ }^{\text {a }}$ Split tree PFTs into tropical, temperate, and boreal groups following the rules of Nemani and Running (1996) that were also used to make CLM land surface data by Lawrence and Chase (2007) since CLM version $3 .^{\mathrm{b}}$ LGG and LGBS did not output PFT-level fire carbon emissions, so land cover is classified using its dominant vegetation type. ${ }^{\mathrm{c}} \mathrm{MC} 2$ classifies tropical savannas and tropical deciduous woodland regions, and the latter mainly represents tropical deciduous forests.

Table 5. Summary description of satellite-based products and historical constructions merged from multiple sources.

\begin{tabular}{|c|c|c|c|c|c|}
\hline Name & Method & Fire data sources & $\begin{array}{l}\text { Peat } \\
\text { burning }\end{array}$ & Start year & reference \\
\hline GFED4 & \multirow{4}{*}{$\begin{array}{l}\text { Bottom-up: fuel consumption, } \\
\text { burned area \&active fire counts } \\
\text { (GFED4\&4s), FRP (GFAS1), } \\
\text { active fire counts (FINN1.5), } \\
\text { emis. factor }\end{array}$} & \multirow[t]{2}{*}{ MODIS,VIRS/ATSR } & $\mathrm{Y}$ & 1997 & \multirow[t]{2}{*}{ van der Werf et al. (2017) } \\
\hline GFED4s & & & $\mathrm{Y}$ & 1997 & \\
\hline GFAS1.2 & & MODIS & $\mathrm{Y}$ & 2001 & Kaiser et al. (2012) \\
\hline FINN1.5 & & MODIS & $\mathrm{N}$ & 2003 & Wiedinmyer et al. (2011) \\
\hline FEER1 & \multirow{2}{*}{$\begin{array}{l}\text { Top-down: FRP, satellite AOD } \\
\text { constrained, emis. factor }\end{array}$} & MODIS, SEVIRI & $\mathrm{Y}$ & 2003 & Ichoku and Ellison (2014) \\
\hline QFED2.5 & & MODIS & $\mathrm{N}$ & 2001 & Darmenov and da Silva (2015) \\
\hline CMIP5 & $\begin{array}{l}\text { Merged decadal fire trace } \\
\text { and aerosol emis. }\end{array}$ & $\begin{array}{l}\text { GFED2, GICC, RETRO } \\
\text { (model GlobFIRM used) }\end{array}$ & $\mathrm{Y}$ & 1850 & Lamarque et al. (2010) \\
\hline CMIP6 & $\begin{array}{l}\text { Merged monthly fire carbon } \\
\text { emis., present-day veg. dist., } \\
\text { emis. factor }\end{array}$ & $\begin{array}{l}\text { GFED4s, median of six } \\
\text { FireMIP model sims., } \\
\text { GCDv3 charcoal records, } \\
\text { WMO visibility obs. }\end{array}$ & $\mathrm{Y}$ & 1750 & van Marle et al. (2017b) \\
\hline
\end{tabular}

Abbreviations: GFED4: Global Fire Emissions Dataset version 4; GFED4s: GFED4 with small fires; GFAS1.2: Global Fire Assimilation System version 1.2; FINN1.5: Fire Inventory from NCAR version 1.5; FRP: fire radiative power; FEER1: fire emissions from the Fire Energetics and Emissions Research version 1; QFED2.5: Quick Fire Emissions Dataset version 2.5; AOD: aerosol optical depth; GFED2: GFED version 2; RETRO: REanalysis of the TROpospheric chemical composition; GICC: Global Inventory for Chemistry-Climate studies; GCDv3: Global Charcoal Database version 3. 
Table 6. Global total of fire emissions from 2003 to 2008 for DGVMs in FireMIP and benchmarks. Unit: $\mathrm{Pg}\left(\mathrm{Pg}=10^{15} \mathrm{~g}\right)$.

\begin{tabular}{lrrrrrrr}
\hline Source & $\mathrm{C}$ & $\mathrm{CO}_{2}$ & $\mathrm{CO}$ & $\mathrm{CH}_{4}$ & $\mathrm{BC}$ & $\mathrm{OC}$ & $\mathrm{PM}_{2.5}$ \\
\hline FireMIP & & & & & & & \\
\hline CLM4.5 & 2.1 & 6.5 & 0.36 & 0.018 & 0.0021 & 0.02 & 0.042 \\
CTEM & 3 & 8.9 & 0.48 & 0.025 & 0.0028 & 0.03 & 0.06 \\
JSBACH & 2.1 & 6.5 & 0.32 & 0.013 & 0.002 & 0.016 & 0.036 \\
JULES & 2.1 & 6.9 & 0.44 & 0.024 & 0.0022 & 0.02 & 0.039 \\
LGG & 4.9 & 15.4 & 0.9 & 0.047 & 0.005 & 0.048 & 0.097 \\
LGS & 1.7 & 5.6 & 0.26 & 0.011 & 0.0017 & 0.012 & 0.027 \\
LGSB & 2.5 & 7.7 & 0.48 & 0.025 & 0.0025 & 0.024 & 0.047 \\
MC2 & 1 & 3.1 & 0.18 & 0.008 & 0.0011 & 0.012 & 0.025 \\
ORCHIDEE & 2.8 & 9.2 & 0.44 & 0.018 & 0.0029 & 0.02 & 0.045 \\
\hline Benchmarks & & & & & & & \\
\hline GFED4 & 1.5 & 5.4 & 0.24 & 0.011 & 0.0013 & 0.012 & 0.025 \\
GFED4s & 2.2 & 7.3 & 0.35 & 0.015 & 0.0019 & 0.016 & 0.036 \\
GFAS1.2 & 2.1 & 7 & 0.36 & 0.019 & 0.0021 & 0.019 & 0.03 \\
FINN1.5 & 2 & 7 & 0.36 & 0.017 & 0.0021 & 0.022 & 0.039 \\
FEER1 & 4.2 & 14 & 0.65 & 0.032 & 0.0042 & 0.032 & 0.054 \\
QFED2.5 & - & 8.2 & 0.39 & 0.017 & 0.006 & 0.055 & 0.086 \\
\hline
\end{tabular}

African rainforests. CLM4.5 and LPJ-GUESS-GlobFIRM overestimate fire emissions over eastern China. JSBACHSPITFIRE underestimates fire emissions in most tropical forests. MC2 underestimates fire emissions over most regions, partly because it allows only one ignition per year per grid cell and thus underestimates the burned area.

We further analyze the spatial distribution of inter-model differences. As shown in Fig. 3, the main disagreement among FireMIP models occurs in the tropics, especially over the tropical savannas in Africa, South America, and northern Australia. This is mainly driven by the MC2, CTEM, JSBACH-SPITFIRE, and ORCHIDEE-SPITFIRE simulations (Fig. 2). Differences among the satellite-based estimates have a similar spatial pattern, but higher than the intermodel spread in savannas over southern Africa and lower in the temperate arid and semi-arid regions and north of $60^{\circ} \mathrm{N}$ over Eurasia (Fig. S1a in the Supplement).

\subsection{Seasonal cycle}

The FireMIP models reproduce similar seasonality features of fire emissions to satellite-based products; that is, peak month is varied from the dry season in the tropics to the warm season in the extra-tropics (Fig. 4).

For the tropics in the Southern Hemisphere, fire $\mathrm{PM}_{2.5}$ emissions of satellite-based products peak in AugustSeptember. Most FireMIP models can reproduce this pattern, except ORCHIDEE-SPITFIRE and LPJ-GUESS-SPITFIRE peaking 2 months and 1 month earlier, respectively, and JSBACH-SPITFIRE with a much lower amplitude of seasonal variability likely caused by parameter setting in its fuel moisture functions (Table S9 in Rabin et al., 2017).
For the tropics in the Northern Hemisphere, most FireMIP models exhibit larger fire emissions in the northern winter, consistent with the satellite-based products.

In the northern extra-tropical regions, satellite-based products show two periods of high values: April-May resulting mainly from fires in croplands and grasslands and July mainly due to fires in the boreal evergreen forests. Most FireMIP models can reproduce the second one, except for LPJ-GUESS-SPITFIRE, which peaks in October. CLM4.5 is the only model that can capture both peak periods, partly because it is the only one to consider unique seasonality of crop fires.

\subsection{Interannual variability}

Global fire $\mathrm{PM}_{2.5}$ emissions from satellite-based products for 1997-2012 show a substantial interannual variability, which peaks in 1997-1998, followed by a low around 2000 and a decline starting in 2002-2003 (Fig. 5). The 1997-1998 high emission values are caused by peat fires in equatorial Asia in 1997 and widespread drought-induced fires in 1998 associated with the most powerful El Niño event in 1997-1998 recorded in history (van der Werf et al., 2017; Kondo et al., 2018). Most FireMIP models cannot reproduce the 19971998 peak, except for CLM4.5 as the only model that simulates the burning of plant tissue and litter from peat fires (although burning of soil organic matter is not included) and the drought-linked tropical deforestation and degradation fires (Li et al., 2013; Kondo et al., 2018). CLM4.5, CTEM, and LPJ-GUESS-SIMFIRE-BLAZE present the highest temporal correlation between models and satellite-based products (0.55-0.79 for CLM4.5, 0.51-0.68 for CTEM, and 0.39- 
(a) CLM4.5 (0.46-0.55)

(b) CTEM (0.29-0.45)

(c) JSBACH (0.12-0.37)

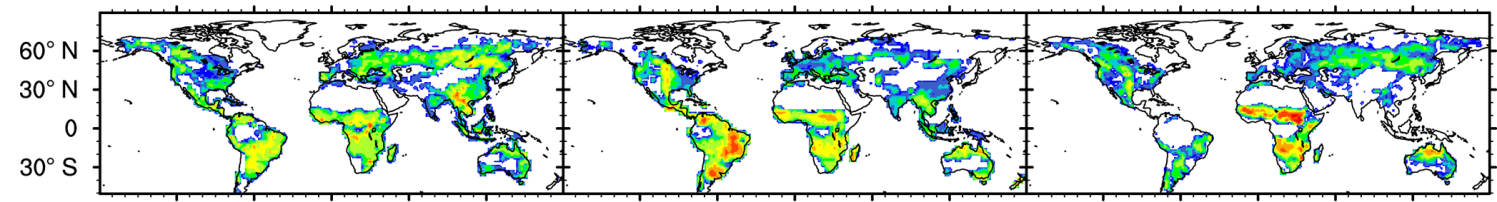

(d) JULES (0.41-0.64)

(e) LGG (0.40-0.51)

(f) LGS (0.23-0.40)

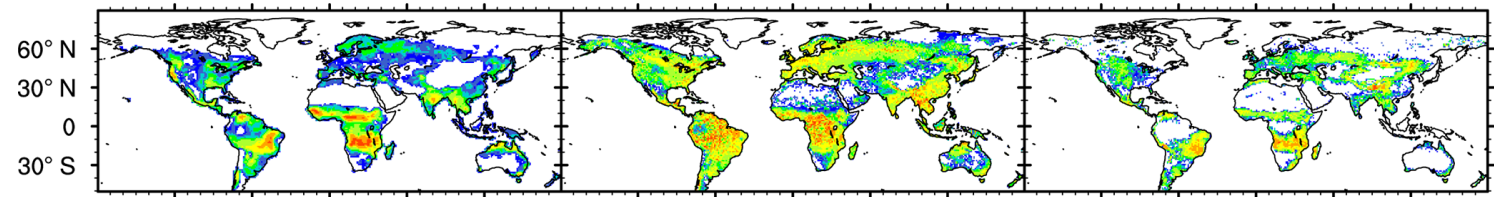

(g) LGSB (0.51-0.63)

(h) MC2 (0.10-0.15)

(i) ORCHIDEE (0.27-0.55)

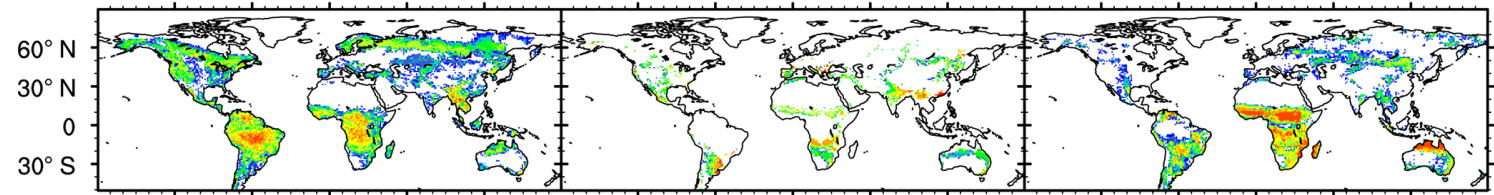

(j) GFED4

(k) GFED4s

(I) GFAS1.2

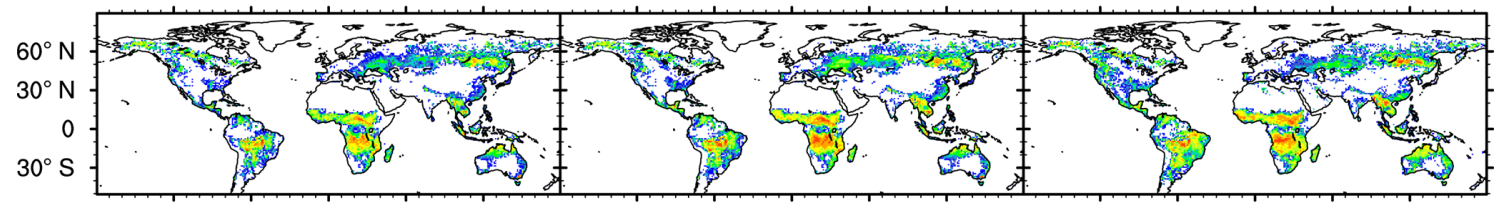

(m) FINN1.5

(n) FEER1

(0) QFED2.5

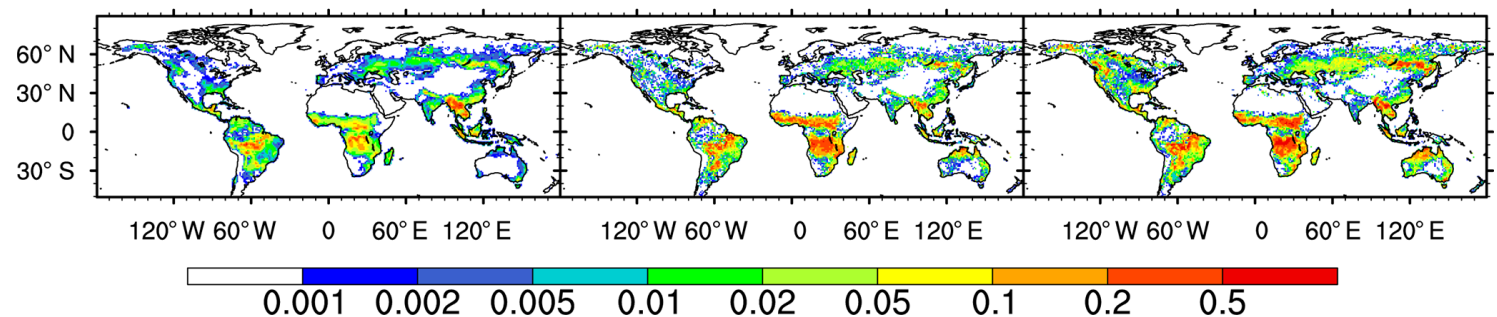

Figure 2. Spatial distribution of annual fire black carbon (BC) emissions $\left(\mathrm{g} \mathrm{BC} \mathrm{m}^{-2} \mathrm{yr}^{-1}\right)$ averaged over 2003-2008. The range of global spatial correlation between DGVMs and satellite-based products is also given in parentheses.

0.72 for LPJ-GUESS-SIMFIRE-BLAZE), and thus are more skillful than other models at reproducing the interannual variability observed from satellite-based products (Table 7).

We use the coefficient of variation $(\mathrm{CV}$, the standard deviation divided by the mean, \%) to represent the amplitude of interannual variability of fire emissions. As shown in Fig. 5, for 1997-2012, all FireMIP models underestimate the variation as a result of (at least) partially missing the 1997-1998 fire emission peak. For 2003-2012 (the common period of all satellite-based products and models), interannual variation of annual fire $\mathrm{PM}_{2.5}$ emissions in CLM4.5, CTEM, and LPJGUESS family models lies within the range of satellite-based products $(\mathrm{CV}=6 \%-12 \%)$. Other models present weaker variation $(\mathrm{CV}=5 \%)$ except for MC2 $(\mathrm{CV}=24 \%)$, which has a much stronger variation than all satellite-based products and other FireMIP models.

\section{Historical changes and drivers}

\subsection{Historical changes}

Figure 6 shows historical simulations of the FireMIP models as well as the CMIP5 and CMIP6 reconstructions for fire carbon, $\mathrm{CO}_{2}, \mathrm{CO}$, and $\mathrm{PM}_{2.5}$ emissions. We find similar historical changes for all the species, with the maximum global fire emissions given by LPJ-GUESS-GlobFIRM and the minima by LPJ-GUESS-SPITFIRE before 1901 and MC 2 afterwards.

Long-term trends in simulated global fire emissions for all models are weak before the 1850s (relative trend $<0.015 \% \mathrm{yr}^{-1}$ ). They are similar to CMIP6 estimates (Fig. 6) but in disagreement with earlier reconstructions based on charcoal records (Marlon et al., 2008, 2016), icecore CO records (Wang et al., 2010), and ice-core $\delta^{13} \mathrm{CH}_{4}$ records (Ferretti et al., 2005), which exhibit a rapid increase from 1700 to roughly the 1850s. After the 1850 s, 


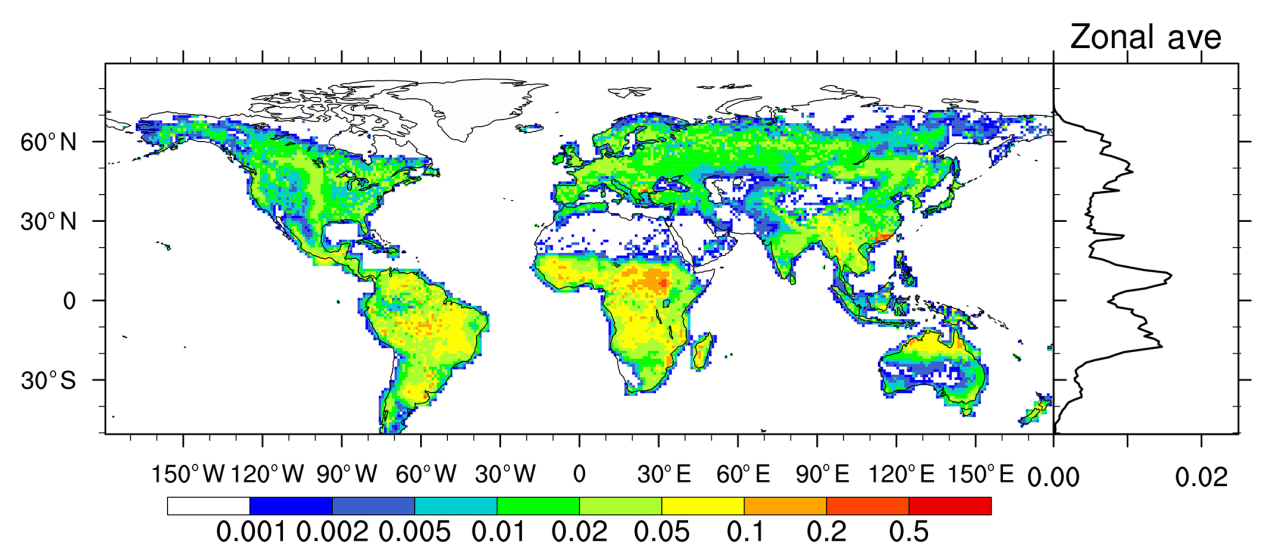

Figure 3. Inter-model standard deviation of 2003-2008 averaged fire $\mathrm{BC}$ emissions $\left(\mathrm{g} \mathrm{BC} \mathrm{m}^{-2} \mathrm{yr}^{-1}\right)$ in FireMIP models and the zonal average.

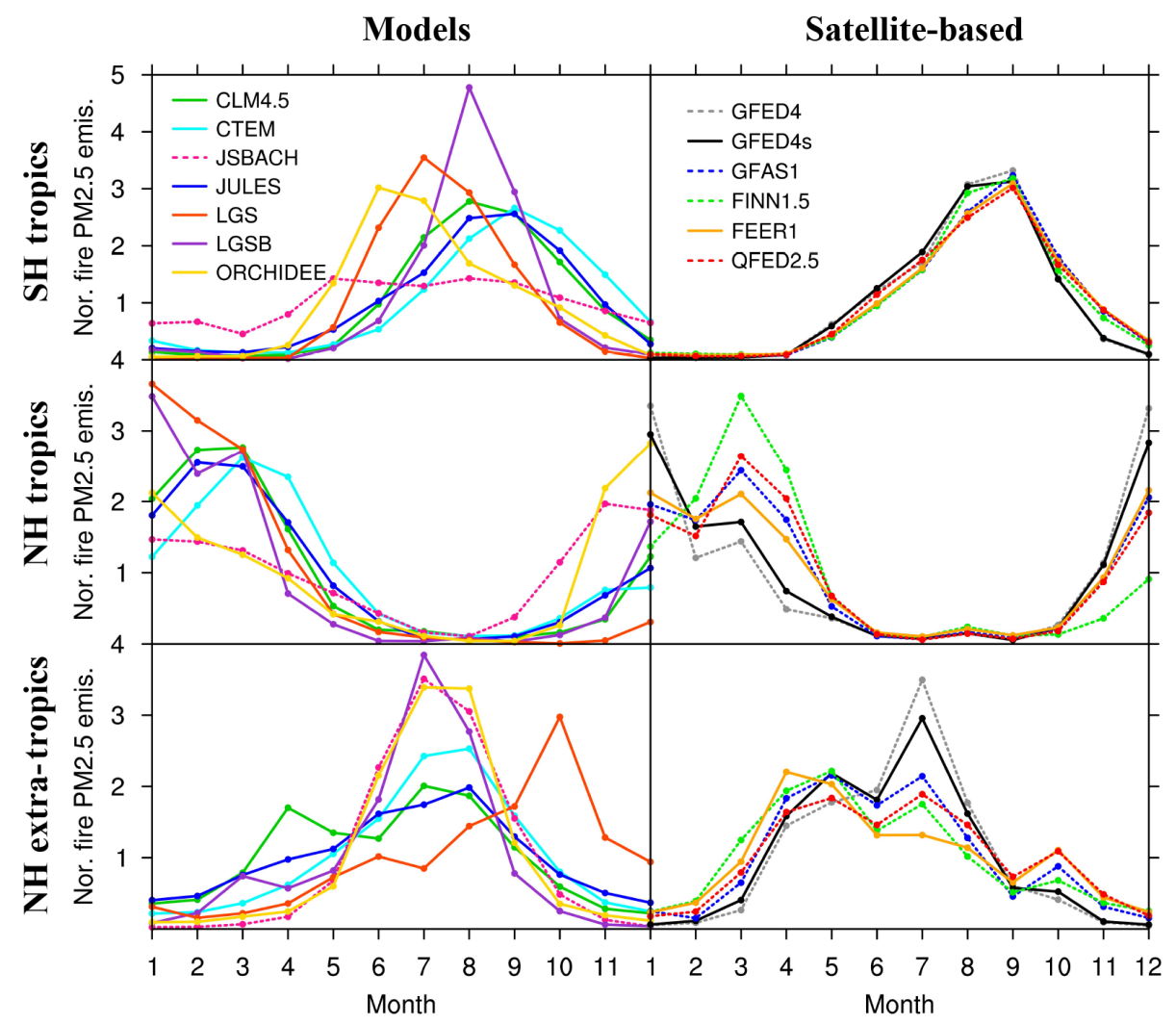

Figure 4. Seasonal cycle of fire $\mathrm{PM}_{2.5}$ emissions normalized by the mean from FireMIP models and satellite-based products averaged over 2003-2008 in the Southern Hemisphere (SH) tropics (0-23.5 $\left.{ }^{\circ} \mathrm{S}\right)$, Northern Hemisphere $(\mathrm{NH})$ tropics $\left(0-23.5^{\circ} \mathrm{N}\right)$, and NH extra-tropics $\left(23.5-90^{\circ} \mathrm{N}\right)$. Fire emissions from LPJ-GUESS-GlobFIRM and MC2 are updated annually and are thus not included here.

disagreement in the trends among FireMIP models begins to emerge. Fire emissions in LPJ-GUESS-SIMFIREBLAZE decline from $\sim 1850$, while fire emissions in LPJGUESS-SPITFIRE, MC2, and ORCHIDEE-SPITFIRE show upward trends from the $\sim 1900$ s. In CLM4.5, CTEM, and JULES-INFERNO, fire emissions increase slightly before $\sim 1950$, similar to the CMIP6 estimates, but CTEM and
JULES-INFERNO decrease thereafter, contrary to CMIP5 and CMIP6 estimates and CLM4.5. JSBACH-SPITFIRE simulates a decrease in fire emissions before the 1940s and an increase later, similar to the CMIP5 estimates. All the longterm trends described above are significant at the 0.05 level using the Mann-Kendall trend test. 
Table 7. Temporal correlation of annual global fire $\mathrm{PM}_{2.5}$ emissions between FireMIP models and satellite-based GFED4 and GFED4s (1997-2012), GFAS1.2 and QFED2.5 (2001-2012), and FINN1.5 and FEER1 (2003-2012).

\begin{tabular}{lrrrrrr}
\hline DGVMs & GFED4 & GFED4s & GFAS1.2 & FINN1.5 & FEER1 & QFED2.5 \\
\hline CLM4.5 & $0.73^{* * *}$ & $0.79^{* * *}$ & $0.63^{* *}$ & $0.62^{*}$ & $0.55^{*}$ & $0.58^{* *}$ \\
CTEM & $0.51^{* *}$ & $0.54^{* *}$ & $0.63^{* *}$ & $0.60^{*}$ & 0.52 & $0.68^{* *}$ \\
JSBACH & -0.18 & -0.42 & 0.1 & 0.02 & -0.04 & 0.32 \\
JULES & 0.33 & 0.31 & 0.31 & $0.56^{*}$ & 0.29 & 0.39 \\
LGG & 0.08 & 0.03 & -0.15 & 0.01 & -0.20 & -0.03 \\
LGS & 0.12 & 0.04 & -0.00 & 0.4 & -0.01 & 0.08 \\
LGSB & $0.51^{* *}$ & $0.64^{* * *}$ & 0.39 & $0.72^{* *}$ & $0.56^{*}$ & $0.55^{*}$ \\
ORCHIDEE & -0.13 & -0.25 & -0.16 & 0.29 & -0.10 & -0.10 \\
\hline
\end{tabular}
$*, * *$ and ${ }^{* * *}$ : Pearson correlation passed the Student's $t$ test at the $0.1,0.05$, and 0.01 significance levels,
respectively.

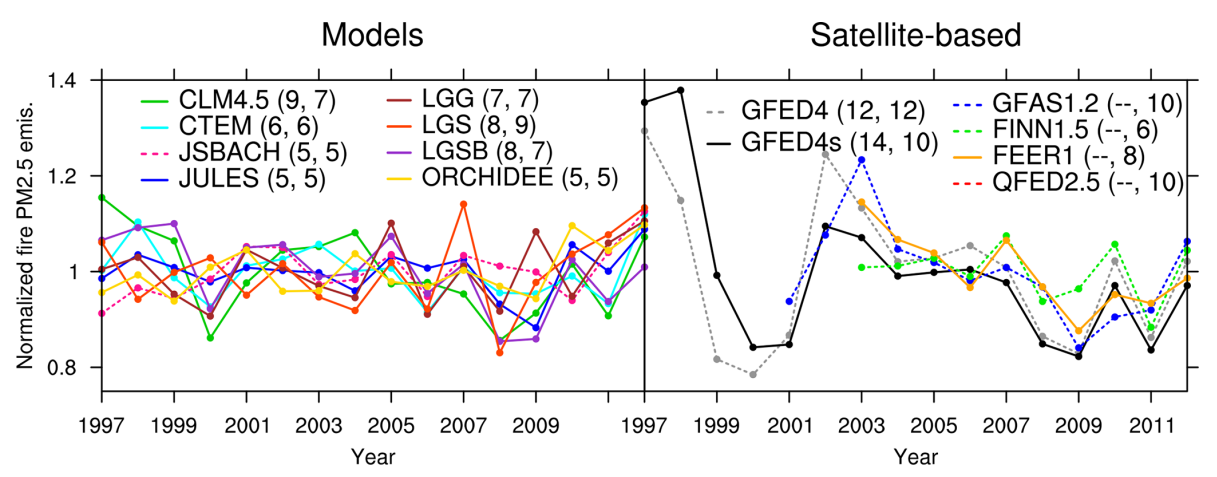

Figure 5. Temporal change in annual global fire $\mathrm{PM}_{2.5}$ emissions normalized by the mean from FireMIP models and satellite-based products. The numbers in parentheses are coefficients of variation (CVs, the standard deviation divided by the mean, unit: \%) for 1997-2012 and 20032012, respectively.

Earlier reconstructions based on fire proxies also show a big difference in long-term changes after the 1850s. The reconstruction based on the Global Charcoal Database version 3 (GCDv3, Marlon et al., 2016) exhibits a decline from the late 19th century to the 1920s and then an upward trend until $\sim 1970$, followed by a drop. The reconstructions based on the GCDv1 (Marlon et al., 2008) and ice-core CO records (Wang et al., 2010) show a sharp drop since roughly the 1850s, while a steady rise is exhibited in the reconstruction based on icecore $\delta^{13} \mathrm{CH}_{4}$ records (Ferretti et al., 2005). The simulated historical changes in FireMIP models (Fig. 6) fall into this fairly broad range of long-term trends in these reconstructions.

Spatial patterns of inter-model spread of fire emissions for 1700-1850 and 1900-2000 (Fig. S1b-c) are similar to the present-day patterns as shown in Fig. 3.

\subsection{Drivers}

Six FireMIP models also conducted sensitivity experiments, which can be used to isolate the role of individual forcing factors in long-term trends of fire emissions during the 20th century. The medians of the six models are also used for building CMIP6 fire emission estimates (van Marle et al., 2017b). The 20th century changes in driving forces used in FireMIP are characterized by an increase in the global land temperature, precipitation, lightning frequency, atmospheric $\mathrm{CO}_{2}$ concentration, population density, and cropland and pasture areas and a decrease in the global forest area (Teckentrup et al., 2019).

As shown in Figs. 6 and 7, the downward trend of global fire emissions in LPJ-GUESS-SIMFIRE-BLAZE is mainly caused by LULCC and increasing population density. Upward trends in LPJ-GUESS-SPITFIRE and ORCHIDEESPITFIRE are dominated by LULCC and rising population density and $\mathrm{CO}_{2}$ during the 20th century. In CLM4.5 and JULES-INFERNO, upward trends before $\sim 1950$ are attributed to rising $\mathrm{CO}_{2}$, climate change, and LULCC, and the subsequent drop in JULES-INFERNO mainly results from the rising population density and climate change. Long-term changes in global fire emissions in JSBACH-SPITFIRE are mainly driven by LULCC and rising $\mathrm{CO}_{2}$.

As shown in Fig. 7, the inter-model spread in longterm trends mainly arises from the simulated anthropogenic influence (LULCC and population density change) on fire emissions, as the standard deviation in simulated re- 

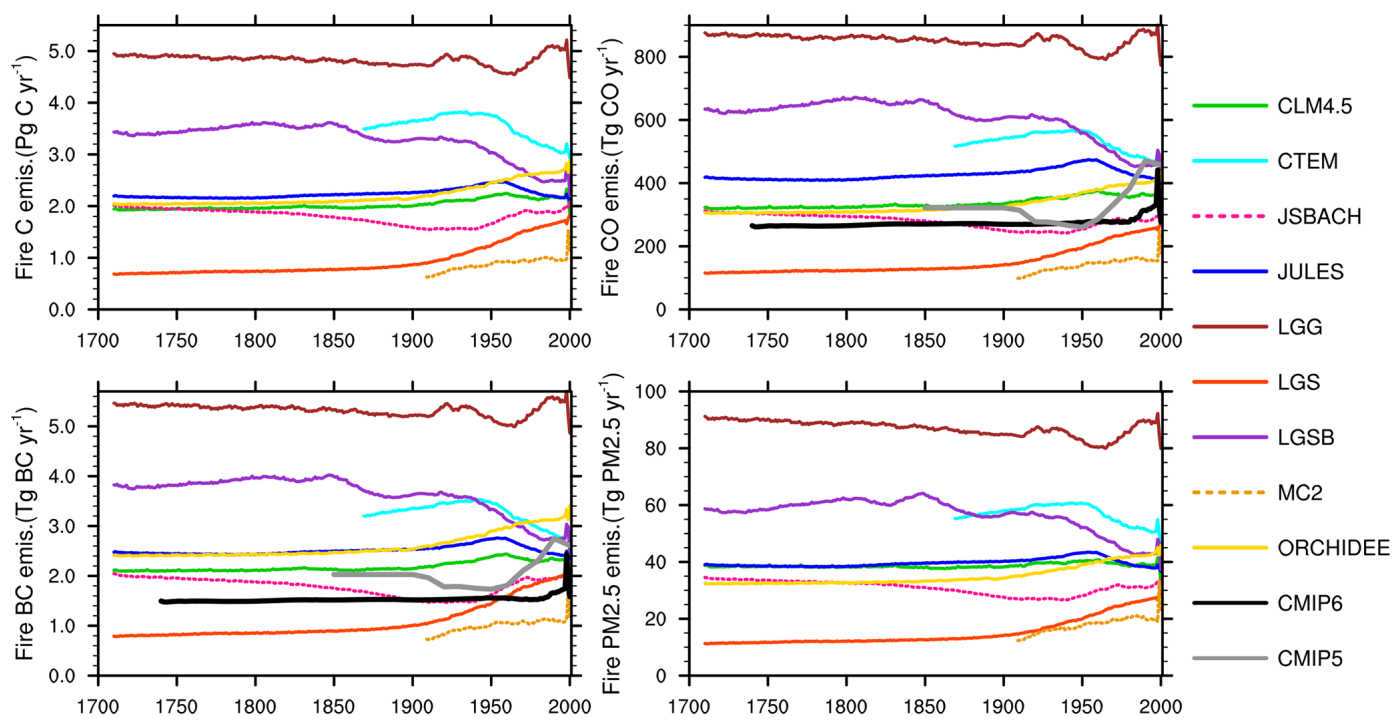

Figure 6. Long-term temporal change in fire emissions from DGVMs in FireMIP and CMIP forcing. A 21-year running mean is used.

sponses to LULCC $\left(0.27 \mathrm{PgC}^{-1}\right)$ and population density $\left(0.11 \mathrm{Pg} \mathrm{C} \mathrm{yr}^{-1}\right)$ is much larger than the other drivers.

LULCC decreases global fire emissions sharply in LPJGUESS-SIMFIRE-BLAZE during the 20th century but increases global fire emissions for the other models except for JSBACH-SPITFIRE. The response to LULCC in LPJGUESS-SIMFIRE-BLAZE is because it assumes no fire in croplands and accounts for biomass harvest (thus reducing fuel availability) in pastures (Table 2), the area of which expanded over the 20th century. The LULCC-induced increases in fire emissions for ORCHIDEE-SPITFIRE, LPJ-GUESSSPITFIRE, and JULES-INFERNO are partly caused by increased burned area due to the expansion of grasslands (pastures are lumped in natural grasslands in these models) where fuels are easier to burn than woody vegetation in the model setups (Rabin et al., 2017). CLM4.5 models crop fires and tropical deforestation and degradation fires. Crop fire emissions in CLM4.5 are estimated to increase during the 20th century due to expansion of croplands and increased fuel loads over time (Fig. S2). Emissions of tropical deforestation and degradation fires in CLM4.5 are increased before $\sim 1950$, responding to increased human deforestation rate in tropical closed forests based on prescribed land use and land cover changes (Li et al., 2018). In JSBACH-SPITFIRE, as croplands and pastures expand over time, the assumption of no fire over croplands tends to decrease fire emissions, while the setting of high fuel bulk density for pastures tends to increase fire emissions due to increased fuel combusted per burned area, which together partly result in the shifted sign of response to LULCC around the 1940s.

Rising population density throughout the 20th century decreases fire emissions in CLM4.5 and LPJ-GUESSSIMFIRE-BLAZE because they include human suppression on both fire occurrence and fire spread. Fire suppression in- creases with rising population density and is simulated explicitly in CLM4.5 and implicitly in LPJ-GUESS-SIMFIREBLAZE. In contrast, rising population density increases fire emissions in LPJ-GUESS-SPITFIRE and ORCHIDEESPITFIRE because observed human suppression on fire spread found in Li et al. (2013), Hantson et al. (2015), and Andela et al. (2017) is not taken into account in the two models. The response to population density change for the other models is small, reflecting the compensating effects of human ignition and human suppression on fire occurrence (strongest in JULES-INFERNO in FireMIP models) and also human suppression on fire duration (JSBACH-SPITFIRE).

All models simulate increased fire emissions with increased atmospheric $\mathrm{CO}_{2}$ concentration since elevated $\mathrm{CO}_{2}$ increases the fuel load. Elevated $\mathrm{CO}_{2}$ increases both the photosynthetic uptake of $\mathrm{CO}_{2}$ (Mao et al., 2009) and plant wateruse efficiency (i.e., less water stress on plant growth and succession, Keenan et al., 2013), that is, $\mathrm{CO}_{2}$ fertilization effect, which can stimulate carbon uptake and storage by the terrestrial biosphere. Such a $\mathrm{CO}_{2}$-driven increase in fuel load is consistent with a recent analysis of satellite-derived vegetation indices (Zhu et al., 2016). FireMIP models also agree that impacts of changes in lightning frequency on long-term trends of fire emissions are small. Moreover, most FireMIP models agree that climate change tends to increase fire carbon emissions during the first several decades and then falls, reflecting co-impacts of climate on both fuel load and fuel moisture.

\subsection{Regional long-term changes}

We divided the global map into 14 regions following the definition of the GFED family (Fig. 8a). As shown in Fig. 8b, inter-model discrepancies in long-term changes are largest 


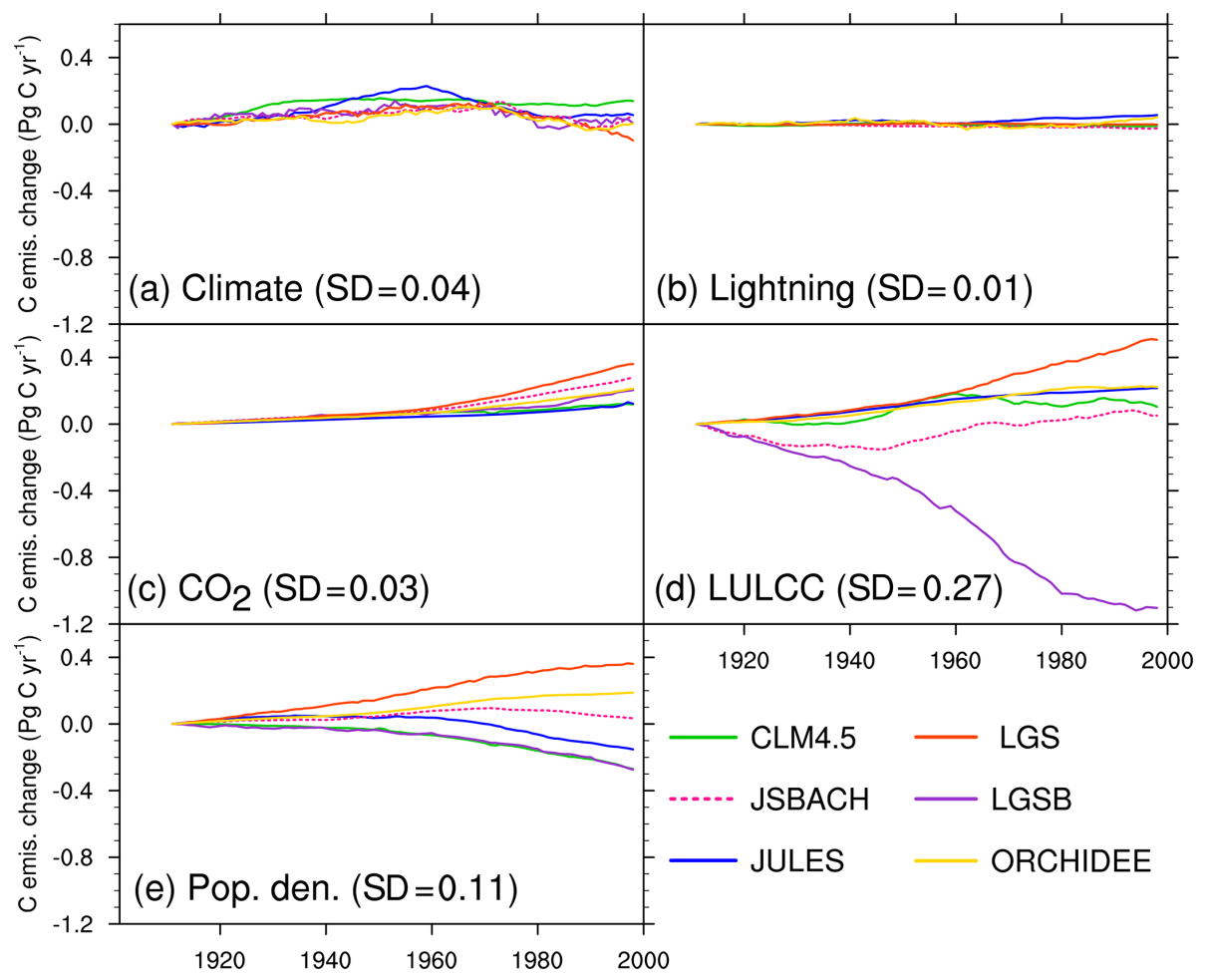

Figure 7. Change in global annual fire carbon emissions $\left(\mathrm{Pg} \mathrm{C} \mathrm{yr}^{-1}\right)$ in the 20th century due to changes in (a) climate, (b) lightning frequency, (c) atmospheric $\mathrm{CO}_{2}$ concentration, (d) land use and land cover change (LULCC), and (e) population density (control run-sensitivity run). A 21-year running mean is used. The standard deviations (SDs) of multi-model simulated long-term changes averaged over the 20th century are also given in parentheses. The control run is a normal transient run, and the five sensitivity runs are similar to the control run but without change in climate, lightning frequency, atmospheric $\mathrm{CO}_{2}$ concentration, land cover, and population density, respectively. The 20th century changes in driving forces used in FireMIP are characterized by an increase in the global land temperature, precipitation, lightning frequency, atmospheric $\mathrm{CO}_{2}$ concentration, and population density, expansion of croplands and pastures, and a decrease in the global forest area.

in Southern Hemisphere South America (SHSA), southern and northern Africa (NHAF and SHAF), and central Asia (CEAS).

Most FireMIP models reproduce the upward trends of fire $\mathrm{CO}$ emissions found also in the CMIP5 or CMIP6 estimates since the 1950s in SHSA and till $\sim 1950$ in Africa (Fig. 9e, h, and i). Long-term trends in regional fire emissions in SHSA, Africa, and central Asia can broadly explain the upward trends in global fire emissions in LPJ-GUESS-SPITFIRE, MC2, and ORCHIDEE-SPITFIRE, the downward trends in LPJ-GUESS-SIMFIRE-BLAZE, and the rise followed by a drop in CTEM, whose global fire emissions exhibit most obvious long-term trends in FireMIP models (Fig. 6).

In other regions, the difference in long-term changes among models is smaller (Fig. 8b). Emissions of most models and CMIP5 estimates exhibit a significant decline in temperate North America (TENA) from $\sim 1850$ to $\sim 1970$, while historical changes in CMIP6 estimates are comparatively small (Fig. 9b). LPJ-GUESS-SIMFIRE-BLAZE has a more obvious long-term change than the other FireMIP models and CMIPs in boreal North America (BONA) and northern South America (NHSA) (Fig. 9a and d). MC2 and LPJ-
GUESS-GlobFIRM emissions increase after $\sim 1900$ in Europe (EURO), while emissions of other models and CMIPs are overall constant (Fig. 9f). In boreal Asia (BOAS), emissions of most models and CMIP6 are relatively constant, while LPJ-GUESS-GlobFIRM and CMIP5 emissions decline from 1850 to the 1950s and from 1900 to the 1970s, respectively, and then rise (Fig. 9j). JULES, LPJ-GUESSSIMFIRE-BLAZE, CLM4.5, CTEM, and CMIP6 emissions significantly decline since the 1950s in Southeast Asia (SEAS), while CMIP5 emissions increase (Fig. 91). In equatorial Asia (EQAS), CMIPs emissions increase after 1950, which is partly reproduced by only CLM4.5 in FireMIP (Fig. 9m).

As shown in Figs. S3-S5, long-term changes in regional fire emissions for other species are similar to those of fire $\mathrm{CO}$ emissions.

The long-term changes in regional fire emissions and intermodel disagreement are mainly caused by simulated responses to LULCC and/or population density change for the 20th century (Figs. S6-S19). Besides, climate change also plays an important role in North America, northern South America, Europe, northern Africa, boreal and central Asia, 

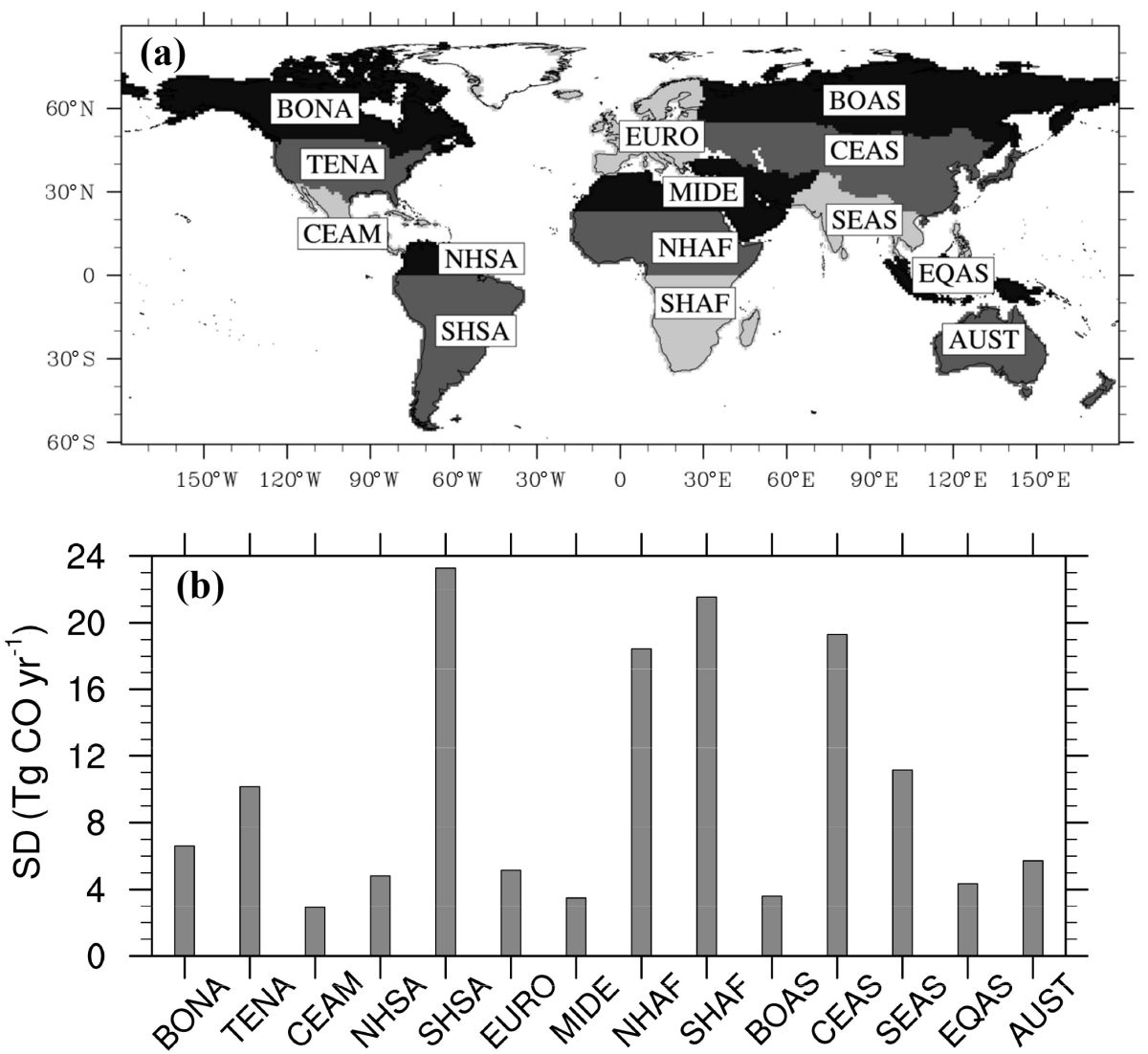

Figure 8. (a) GFED region definition (http://www.globalfiredata.org/data.html, last access: 2 October 2018) and (b) inter-model discrepancy (quantified using inter-model standard deviation) in long-term changes (a 21-year running mean is used, relative to the present day) of sim-

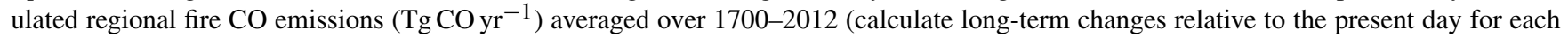
FireMIP model first, then the inter-model standard deviation, and lastly the time average). The abbreviations are BONA: boreal North America; TENA: temperate North America; CEAM: central America; NHSA: Northern Hemisphere South America; SHSA: Southern Hemisphere South America; EURO: Europe; MIDE: Middle East; NHAF: Northern Hemisphere Africa; SHAF: Southern Hemisphere Africa; BOAS: boreal Asia; CEAS: central Asia; SEAS: Southeast Asia; EQAS: equatorial Asia; AUST: Australia.

and Australia. FireMIP models generally simulate increased regional fire emissions with increased $\mathrm{CO}_{2}$ concentration and negligible impacts due to changes in lightning frequency, similar to the responses of global fire emissions.

\section{Summary and outlook}

Our study provides the first multi-model reconstructions of global historical fire emissions for 1700-2012, including carbon and 33 species of trace gases and aerosols. Two versions of the fire emission product are available, at the original spatial resolution for outputs of each FireMIP model and on a unified $1 \times 1^{\circ}$. The dataset is based on simulations of fire carbon emissions and vegetation distribution from nine DGVMs with state-of-the-art global fire models that participated in FireMIP and the most up-to-date emission factors over various land cover types. It will be available to the public at https://doi.org/10.5281/zenodo.3386620.
Our study provides an important dataset with wideranging applications for the Earth science research community. First, it is the first multi-model-based reconstruction of fire emissions and can serve as a basis for further development of multi-source merged products of global and regional fire emissions and of the merging methodology itself. van Marle et al. (2017b) presented an example of using part of the dataset to develop a multi-source merged fire emission product as a forcing dataset for CMIP6. In van Marle et al. (2017b), the median of fire carbon emissions from six FireMIP models was used to determine historical changes over most regions of the world. The merging method and merged product in van Marle et al. (2017b) are still preliminary and need to be improved in the future, e.g., by weighting the different models depending on their global or regional simulation skills. Secondly, our dataset includes global gridded reconstructions for 300 years. It can thus be used for analyzing global and regional historical changes in fire emissions on interannual to multi-decadal timescales and their in- 


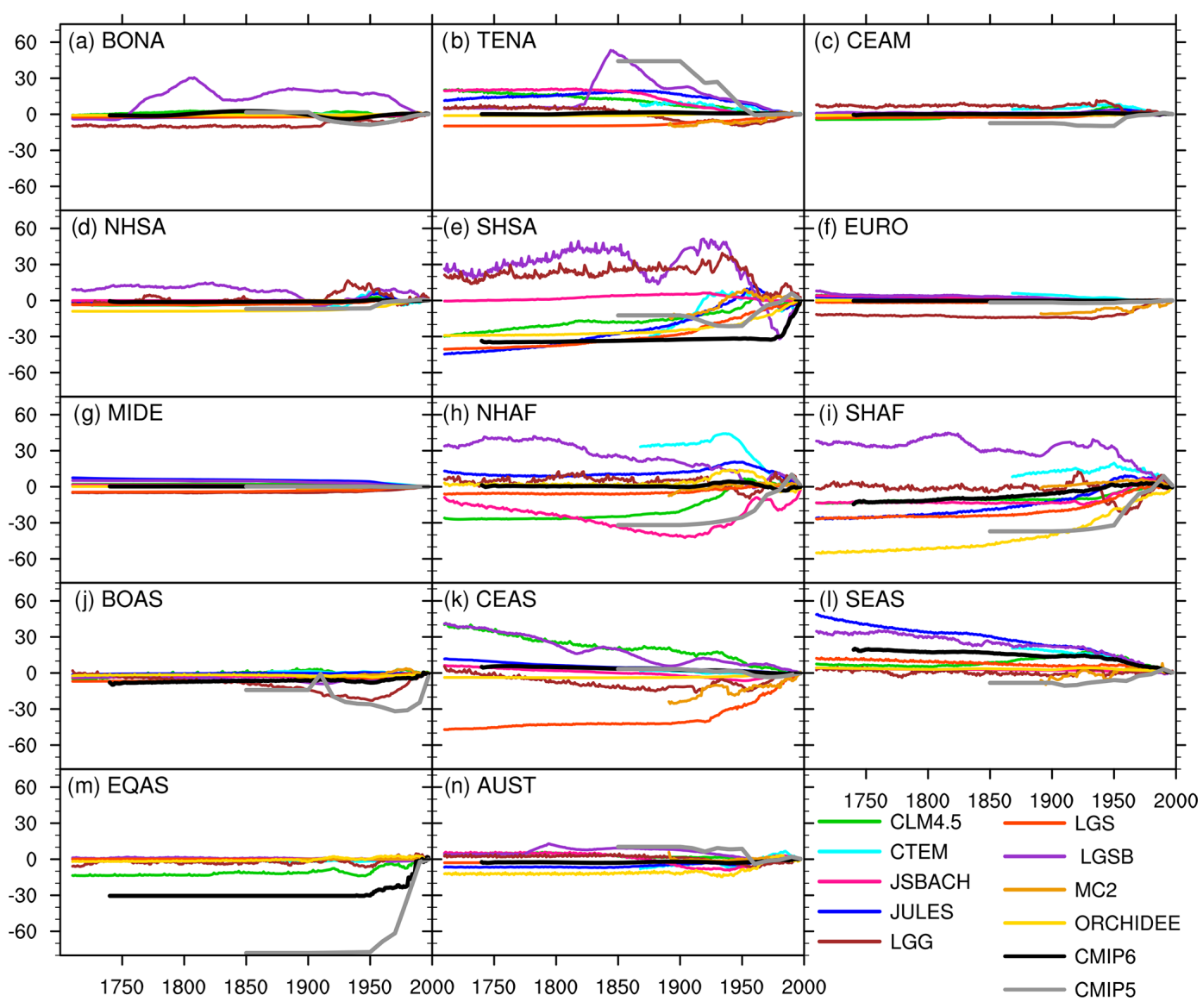

Figure 9. Long-term changes in annual regional fire $\mathrm{CO}$ emissions $\left(\mathrm{Tg} \mathrm{CO} \mathrm{yr}^{-1}\right)$ from FireMIP models and CMIPs. A 21-year running mean is used.

terplay with climate variability and human activities. Third, the fire emission reconstructions based on multiple models provide, for the first time, a chance to quantify and understand the uncertainties in historical changes in fire emissions and their subsequent impacts on carbon cycle, radiative balance, air quality, and climate. Hamilton et al. (2018), for example, used fire emission simulations from two global fire models and the CMIP6 estimates to drive an aerosol model. This allowed for quantification of the impact of uncertainties in pre-industrial fire emissions on estimated pre-industrial aerosol concentrations and historical radiative forcing.

This study also provides significant information on the recent state of fire model performance by evaluating the present-day estimates based on FireMIP fire models (also those used in the upcoming CMIP6). Our results show that most FireMIP models can overall reproduce the amount, spatial pattern, and seasonality of fire emissions shown by satellite-based fire products. Yet they fail to simulate the interannual variability partly due to a lack of modeling peat and tropical deforestation fires. In addition, Teckentrup et al. (2019) found that climate was the main driver of interannual variability for the FireMIP models. A good represen- tation of fire duration may be important to get the response of fire emissions to climate right. However, all FireMIP models limit the fire duration of individual fire events no more than 1 day in natural vegetation regions, so they cannot skillfully model the drought-induced large fires that last multiple days (Le Page et al., 2015; Ward et al., 2018). Recently, Andela et al. (2019) derived a dataset of fire duration from MODIS satellite observations, which provides a valuable dataset for developing parameterization of fire duration in global fire models.

This study also identifies population density and LULCC as the primary uncertainty sources in fire emission estimates. Therefore, accurately modeling the responses to these remains a top priority for reducing uncertainty in historical reconstructions and future projections of fire emissions, especially given that modeling is the only way for future projections. For the response to changes in population density, many FireMIP models have not included the observed relationship between population density and fire spread (Table 2). Moreover, Bistinas et al. (2014) and Parisien et al. (2016) reported obvious spatial heterogeneity of the pop- 
ulation density-burned area relationship that is poorly represented in FireMIP models.

For the response to LULCC, improving the modeling of crop fires, pasture fires, deforestation and degradation fires, and human indirect effect on fires (e.g., fragmentation of the landscape) and reducing the uncertainty in the interpretation of land use datasets in models are critical. Fire has been widely used in agricultural management during the harvesting, post-harvesting, or pre-planting periods (Korontzi et al., 2006; Magi et al., 2012). Crop fire emissions are an important source of greenhouse gases and air pollutants (Tian et al., 2016; Wu et al., 2017; Andreae, 2019). GFED4s reported that fires in croplands can contribute $5 \%$ of burned area and $6 \%$ of fire carbon emissions globally in the present day (Randerson et al., 2012; van der Werf et al., 2017). In FireMIP, only CLM4.5 simulates crop fires, whereas the other models assume no fire in croplands or treat croplands as natural grasslands. In CLM4.5, crop fires contribute $5 \%$ of the global burned area in 2001-2010, similar to GFED4s estimates. However, CLM4.5 estimates a total of $260 \mathrm{Tg} \mathrm{C} \mathrm{yr}^{-1}$ carbon emissions (contribution rate: $13 \%$ ), which is higher

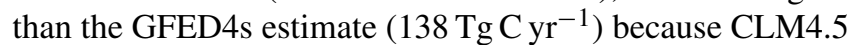
simulates higher fuel loads in croplands than the CASA model used by GFED4s. In CLM4.5, both the carbon emissions from crop fires and the contribution of crop fire emissions to the total fire emissions increase throughout the 20th century (Fig. S2), which is consistent with earlier estimates based on a different crop fire scheme (Ward et al., 2018). In JULES-INFERNO, an increase in cropland area also leads to an increase in burned area and fire carbon emissions because this model treats croplands as natural grasslands. Grasses dry out faster than woody vegetation and are easier to burn, so an increasing cropland area leads to increasing burned area and fire carbon emissions. On the other hand, for FireMIP models that exclude croplands from burning, expansion of croplands leads to a decrease in burned area and fire carbon emissions. Therefore, different treatment of crop fires can contribute to the uncertainty in simulated fire emissions. Since four out of six FireMIP models used for generating CMIP6 estimates exclude croplands from burning (van Marle et al., 2017b), CMIP6 estimates may underestimate the impact of historical changes in crop fire emissions in some regions (e.g., China, Russia, India). Given the small extent of crop fires, high-resolution remote sensing may help improve the detection of crop fires (Randerson et al., 2012; Zhang et al., 2018), which can benefit the driver analyses and modeling of historical crop fires and their emissions in DGVMs.

Le Page et al. (2017) and Li et al. (2018) highlighted the importance of tropical deforestation and degradation fires in the long-term changes in reconstructed and projected global fire emissions, but in FireMIP only CLM4.5 estimates the tropical deforestation and degradation fires. For pasture fires, all FireMIP models assume that they behave like natural grassland fires, which needs to be verified by, for example, satellite-based products. If fires over pastures and natural grasslands are significantly different, adding the gridded coverage of pasture as a new input field in DGVMs without pasture PFTs and developing a parameterization of pasture fires will be necessary. Furthermore, Archibald (2016) and Andela et al. (2017) found that expansion of croplands and pastures decreased fuel continuity and thus reduced burned area and fire emissions. However, no FireMIP model parameterizes this indirect human effect on fires. In addition, DGVMs generalize the global vegetation using different sets of PFTs (Table 4) and represent land use data in a different way. This may lead to different responses of fire emissions to LULCC and thus different long-term changes in fire emissions among model simulations, given that many parameters and functions in global fire models are PFT-dependent. LUH2 used in LUMIP and ongoing CMIP6 provide information on forest/nonforest coverage changes (Lawrence et al., 2016), which can reduce the misinterpretation of the land use data in models and thus the inter-model spread of fire emission changes.

As discussed above, most FireMIP models do not consider the human suppression of fire spread, decreased fuel continuity from expanding croplands and pastures, human deforestation and degradation fires, and crop fires. Therefore, these models, and hence the CMIP6 estimates that are mainly based on them, may have some uncertainties in estimating historical fire emissions and long-term trends. This may further affect the estimates of the radiative forcing of fire emissions and the historical response of trace gas and aerosol concentrations, temperature, precipitation, and energy, water, and biogeochemical cycles to fire emissions based on Earth/climate system models that include these fire models or are driven by such fire emissions. It may also influence future projections of climate and Earth system responses to various population density and land use scenarios.

Data availability. Data of FireMIP fire emissions are freely available from https://doi.org/10.5281/zenodo.3386620 (Li et al., 2019).

Supplement. The supplement related to this article is available online at: https://doi.org/10.5194/acp-19-12545-2019-supplement.

Author contributions. FL contributed to the processing and analyses of the fire emission dataset. SS and AA designed the FireMIP experiments and LF, SH, GL, CY, DB, SM, MF, JM, and TH performed FireMIP simulations. MA compiled the EF table. JK, AD, CI, GvdW, and CW provided satellite-based and CMIP estimates of fire emissions. FL prepared the first draft of manuscript and revised it with contributions from MVM and other co-authors.

Competing interests. The authors declare that they have no conflict of interest. 
Acknowledgements. We are grateful to Robert J. Yokelson, ZhongDa Lin, Samuel Levis, Silvia Kloster, Margreet J. E. van Marle, Ben Bond-Lamberty, Jennifer R. Marlon, and Xu Yue for helpful discussions. We also thank two anonymous reviewers for their valuable comments and suggestions, and the editor Qiang Zhang for handling this paper.

Financial support. This research has been supported by the National Key R\&D Program of China (grant nos. 2017YFA0604302 and 2017YFA0604804), the National Natural Science Foundation of China (grant nos. 41475099 and 41875137), and the CAS Key Research Program of Frontier Sciences (grant no. QYZDYSSW-DQC002). Maria Val Martin is supported by the US Joint Fire Science Program (13-1-01-4) and the UK Leverhulme Trust through a Leverhulme Research Centre Award (RC-2015-029). Almut Arneth acknowledges support from the Helmholtz Association, its ATMO program, and the Impulse and Networking fund, which funded initial FireMIP activities. Almut Arneth and Stijn Hantson also acknowledge EU FP7 project BACCHUS (603445). Gitta Lasslop is funded by the German Research Foundation (338130981). Brian I. Magi is supported by the NSF (BCS-1436496). Charles Ichoku is supported by NASA (NNH12ZDA001N-IDS).

Review statement. This paper was edited by Qiang Zhang and reviewed by Douglas Hamilton and two anonymous referees.

\section{References}

Ahlström, A., Schurgers, G., Arneth, A., and Smith, B.: Robustness and uncertainty in terrestrial ecosystem carbon response to CMIP5 climate change projections, Environ. Res. Lett., 7, 044008, https://doi.org/10.1088/1748-9326/7/4/044008, 2012.

Akagi, S. K., Yokelson, R. J., Wiedinmyer, C., Alvarado, M. J., Reid, J. S., Karl, T., Crounse, J. D., and Wennberg, P. O.: Emission factors for open and domestic biomass burning for use in atmospheric models, Atmos. Chem. Phys., 11, 4039-4072, https://doi.org/10.5194/acp-11-4039-2011, 2011.

Andela, N., Morton, D. C., Giglio, L., Chen, Y., van der Werf, G. R., Kasibhatla, P. S., DeFries, R. S., Collatz, G. J., Hantson, S., Kloster, S., Bachelet, D., Forrest, M., Lasslop, G., Li, F., Mangeon, S., Melton, J. R., Yue, C., and Randerson, J. T.: A humandriven decline in global burned area, Science, 356, 1356-1362, 2017.

Andela, N., Morton, D. C., Giglio, L., Paugam, R., Chen, Y., Hantson, S., van der Werf, G. R., and Randerson, J. T.: The Global Fire Atlas of individual fire size, duration, speed and direction, Earth Syst. Sci. Data, 11, 529-552, https://doi.org/10.5194/essd-11-529-2019, 2019.

Andreae, M. O.: Emission of trace gases and aerosols from biomass burning - an updated assessment, Atmos. Chem. Phys., 19, 8523-8546, https://doi.org/10.5194/acp-19-8523-2019, 2019.

Andreae, M. O. and Merlet, P.: Emission of trace gases and aerosols from biomass burning, Global Biogeochem. Cy., 15, 955-966, 2001.
Andreae, M. O. and Rosenfeld, D.: Aerosol-cloud- precipitation interactions, Part 1, The nature and sources of cloud-active aerosols, Earth-Sci. Rev., 89, 13-41, https://doi.org/10.1016/j.earscirev.2008.03.001, 2008.

Archibald, S.: Managing the human component of fire regimes: lessons from Africa, Philos. T. R. Soc. B., 371, 20150346, https://doi.org/10.1098/rstb.2015.0346, 2016.

Arora, V. K. and Boer, G.: Fire as an interactive component of dynamic vegetation models, J. Geophys. Res., 110, G02008, https://doi.org/10.1029/2005JG000042, 2005.

Bachelet, K., Ferschweiler, T. J., Sheehan, B. M., Sleeter, and Zhu, Z.: Projected carbon stocks in the conterminous USA with land use and variable fire regimes, Glob. Change Biol., 21, 45484560, 2015.

Best, M. J., Pryor, M., Clark, D. B., Rooney, G. G., Essery, R. L. H., Ménard, C. B., Edwards, J. M., Hendry, M. A., Porson, A., Gedney, N., Mercado, L. M., Sitch, S., Blyth, E., Boucher, O., Cox, P. M., Grimmond, C. S. B., and Harding, R. J.: The Joint UK Land Environment Simulator (JULES), model description Part 1: Energy and water fluxes, Geosci. Model Dev., 4, 677-699, https://doi.org/10.5194/gmd-4-677-2011, 2011.

Bistinas, I., Harrison, S. P., Prentice, I. C., and Pereira, J. M. C.: Causal relationships versus emergent patterns in the global controls of fire frequency, Biogeosciences, 11, 5087-5101, https://doi.org/10.5194/bg-11-5087-2014, 2014.

Bond-Lamberty, B., Peckham, S. D., Ahl, D. E., and Gower, S. T.: The dominance of fire in determining carbon balance of the central Canadian boreal forest, Nature, 450, 89-92, 2007.

Bowman, D. M. J. S., Balch, J. K., Artaxo, P., Bond, W. J., Carlson, J. M., Cochrane, M. A., D’Antonio, C. M., DeFries, R. S., Doyle, J. C., Harrison, S. P., Johnston, F. H., Keeley, J. E., Krawchuk, M. A., Kull, C. A., Marston, J. B., Moritz, M. A., Prentice, I. C., Roos, C. I., Scott, A. C., Swetnam, T. W., van der Werf, G. R., and Pyne, S. J.: Fire in the Earth system, Science, 324, 481-484, 2009.

Brovkin, V., Boysen, L., Arora, V. K., Boisier, J. P., Cadule, P., Chini, L., Claussen, M., Friedlingstein, P., Gayler, V., van den Hurk, B. J. J. M., Hurtt, G. C., Jones, C. D., Kato, E., de Noblet-Ducoudré, N., Pacifico, F., Pongratz, J., and Weiss, M.: Effect of anthropogenic land-use and land-cover changes on climate and land carbon storage in CMIP5 projections for the twenty-first century, J. Climate, 26, 6859-6881, https://doi.org/10.1175/JCLI-D-12-00623.1, 2013.

Chen, Y., Randerson, J., van der Werf, G., Morton, D., Mu, M., and Kasibhatla, P.: Nitrogen deposition in tropical forests from savanna and deforestation fires, Glob. Change Biol., 16, 2024 2038, 2010.

Ciais, P., Sabine, C., Bala, G., Bopp, L., Brovkin, V., Canadell, J., Chhabra, A., DeFries, R., Galloway, J., Heimann, M., Jones, C., Le Quéré, C., Myneni, R. B., Piao, S., and Thornton, P.: Carbon and Other Biogeochemical Cycles, In: Climate Change 2013: The Physical Science Basis. Contribution of Working Group I to the Fifth Assessment Report of the Intergovernmental Panel on Climate Change, edited by: Stocker, T. F., Qin, D., Plattner, G.-K., Tignor, M., Allen, S. K., Boschung, J., Nauels, A., Xia, Y., Bex, V., and Midgley, P. M., Cambridge University Press, Cambridge, United Kingdom and New York, NY, USA, 467544, 2013. 
Clark, D. B., Mercado, L. M., Sitch, S., Jones, C. D., Gedney, N., Best, M. J., Pryor, M., Rooney, G. G., Essery, R. L. H., Blyth, E., Boucher, O., Harding, R. J., Huntingford, C., and Cox, P. M.: The Joint UK Land Environment Simulator (JULES), model description - Part 2: Carbon fluxes and vegetation dynamics, Geosci. Model Dev., 4, 701-722, https://doi.org/10.5194/gmd-4701-2011, 2011.

Conedera, M., Tinner, W., Neff, C., Meurer, M., Dickens, A. F., and Krebs, P.: Reconstructing past fire regimes: methods, applications, and relevance to fire management and conservation, Quaternary Sci. Rev., 28, 555-576, https://doi.org/10.1016/j.quascirev.2008.11.005, 2009.

Darmenov, A. S. and da Silva, A.: The Quick Fire Emissions Dataset (QFED): Documentation of versions 2.1, 2.2 and 2.4, in: Technical Report Series on Global Modeling and Data Assimilation, edited by: Koster, R. D., NASA Goddard Space Flight Center; Greenbelt, MD, USA, 212 pp., 2015.

Falk, D. A., Heyerdahl, E. K., Brown, P. M., Farris, C., Fulé, P. Z., McKenzie, D., Swetnam, T. W., Taylor, A. H., and Van Horne, M. L.: Multi-scale controls of historical forest-fire regimes: new insights from fire-scar networks, Front. Ecol. Environ., 9, 446454, 2011

Ferretti, D., Miller, J., White, J., Etheridge, D., Lassey, K., Lowe, D., Meure, C., Dreier, M., Trudinger, C., van Ommen, T., and Langenfelds, R.: Unexpected changes to the global methane budget over the past 2000 years, Science, 309, 1714-1717, https://doi.org/10.1126/science.1115193, 2005.

Field, R. D., van der Werf, G. R., and Shen, S. S. P.: Human amplification of drought-induced biomass burning in Indonesia since 1960, Nat. Geosci., 2, 185-188, https://doi.org/10.1038/ngeo443, 2009.

Fisher, J. A., Jacob, D. J., Purdy, M. T., Kopacz, M., Le Sager, P., Carouge, C., Holmes, C. D., Yantosca, R. M., Batchelor, R. L., Strong, K., Diskin, G. S., Fuelberg, H. E., Holloway, J. S., Hyer, E. J., McMillan, W. W., Warner, J., Streets, D. G., Zhang, Q., Wang, Y., and Wu, S.: Source attribution and interannual variability of Arctic pollution in spring constrained by aircraft (ARCTAS, ARCPAC) and satellite (AIRS) observations of carbon monoxide, Atmos. Chem. Phys., 10, 977-996, https://doi.org/10.5194/acp-10-977-2010, 2010.

Grandey, B. S., Lee, H.-H., and Wang, C.: Radiative effects of interannually varying vs. interannually invariant aerosol emissions from fires, Atmos. Chem. Phys., 16, 14495-14513, https://doi.org/10.5194/acp-16-14495-2016, 2016.

Hamilton, D. S., Hantson, S., Scott, C. E., Kaplan, J. O., Pringle, K. J., Nieradzik, L. P., Rap, A., Folberth, G. A., Spracklen, D. V., and Carslaw, K. S.: Reassessment of pre-industrial fire emissions strongly affects anthropogenic aerosol forcing, Nat. Commun., 9, 3182, https://doi.org/10.1038/s41467-018-05592-9, 2018.

Hantson, S., Pueyo, S., and Chuvieco, E.: Global fire size distribution is driven by human impact and climate, Glob. Ecol. Biogeogr., 24, 77-86, 2015.

Hantson, S., Arneth, A., Harrison, S. P., Kelley, D. I., Prentice, I. C., Rabin, S. S., Archibald, S., Mouillot, F., Arnold, S. R., Artaxo, P., Bachelet, D., Ciais, P., Forrest, M., Friedlingstein, P., Hickler, T., Kaplan, J. O., Kloster, S., Knorr, W., Lasslop, G., Li, F., Mangeon, S., Melton, J. R., Meyn, A., Sitch, S., Spessa, A., van der Werf, G. R., Voulgarakis, A., and Yue, C.: The status and chal- lenge of global fire modelling, Biogeosciences, 13, 3359-3375, https://doi.org/10.5194/bg-13-3359-2016, 2016.

Heymann, J., Reuter, M., Buchwitz, M., Schneising, O., Bovensmann, H., Burrows, J. P., Massart, S., Kaiser, J. W., and Crisp, D.: $\mathrm{CO}_{2}$ emission of Indonesian fires in 2015 estimated from satellite-derived atmospheric $\mathrm{CO}_{2}$ concentrations, Geophys. Res. Lett., 44, 1537-1544, 2017.

Hurtt, G. C., Chini, L. P., Frolking, S., Betts, R. A., Feddema, J., Fischer, G., Fisk, J. P., Hibbard, K., Houghton, R. A., Janetos, A., Jones, C. D., Kindermann, G., Kinoshita, T., Klein Goldewijk, K., Riahi, K., Shevliakova, E., Smith, S., Stehfest, E., Thomson, A., Thornton, P., van Vuuren, D. P., and Wang, Y. P.: Harmonization of land-use scenarios for the period 1500-2100: 600 years of global gridded annual land-use transitions, wood harvest, and resulting secondary lands, Climatic Change, 109, 117161, https://doi.org/10.1007/s10584-011-0153-2, 2011.

Ichoku, C. and Ellison, L.: Global top-down smoke-aerosol emissions estimation using satellite fire radiative power measurements, Atmos. Chem. Phys., 14, 6643-6667, https://doi.org/10.5194/acp-14-6643-2014, 2014.

Jiang, Y., Lu, Z., Liu, X., Qian, Y., Zhang, K., Wang, Y., and Yang, X.-Q.: Impacts of global open-fire aerosols on direct radiative, cloud and surface-albedo effects simulated with CAM5, Atmos. Chem. Phys., 16, 14805-14824, https://doi.org/10.5194/acp-1614805-2016, 2016.

Johnston, F. H., Henderson, S. B., Chen, Y., Randerson, J. T., Marlier, M., DeFries, R. S., Kinney, P., Bowman, D. M. J. S., and Brauer, M.: Estimated global mortality attributable to smoke from landscape fires, Environ. Health Persp., 120, 695-701, https://doi.org/10.1289/ehp.1104422, 2012.

Kaiser, J. W., Heil, A., Andreae, M. O., Benedetti, A., Chubarova, N., Jones, L., Morcrette, J.-J., Razinger, M., Schultz, M. G., Suttie, M., and van der Werf, G. R.: Biomass burning emissions estimated with a global fire assimilation system based on observed fire radiative power, Biogeosciences, 9, 527-554, https://doi.org/10.5194/bg-9-527-2012, 2012.

Keenan, T. F., Hollinger, D. Y., Bohrer, G., Dragoni, D., Munger, J. W., Schmid, H. P., and Richardson, A. D.: Increase in forest water-use efficiency as atmospheric carbon dioxide concentrations rise, Nature, 499, 324-327, 2013.

Klein Goldewijk, K., Beusen, A., and Janssen, P.: Long-term dynamic modeling of global population and built-up area in a spatially explicit way: HYDE 3.1, Holocene, 20, 565-573, https://doi.org/10.1177/0959683609356587, 2010.

Kloster, S. and Lasslop, G.: Historical and future fire occurrence (1850 to 2100) simulated in CMIP5 Earth System Models, Global Planet. Change, 150, 58-69, https://doi.org/10.1016/j.gloplacha.2016.12.017, 2017.

Kloster, S., Mahowald, N. M., Randerson, J. T., Thornton, P. E., Hoffman, F. M., Levis, S., Lawrence, P. J., Feddema, J. J., Oleson, K. W., and Lawrence, D. M.: Fire dynamics during the 20th century simulated by the Community Land Model, Biogeosciences, 7, 1877-1902, https://doi.org/10.5194/bg-7-18772010, 2010.

Knorr, W., Jiang, L., and Arneth, A.: Climate, $\mathrm{CO}_{2}$ and human population impacts on global wildfire emissions, Biogeosciences, 13, 267-282, https://doi.org/10.5194/bg-13-267-2016, 2016.

Knorr, W., Dentener, F., Lamarque, J.-F., Jiang, L., and Arneth, A.: Wildfire air pollution hazard during the 21 st century, At- 
mos. Chem. Phys., 17, 9223-9236, https://doi.org/10.5194/acp17-9223-2017, 2017.

Kondo, M., Ichii, K., Patra, P. K., Canadell, J. G., Poulter, B., Sitch, S., Calle, L., Liu, Y. Y., van Dijk, A. I. J. M., Saeki, T., Saigusa, N., Friedlingstein, P., Arneth, A., Harper, A., Jain, A. K., Kato, E., Koven, C., Li, F., Pugh, T. A. M., Zaehle, S., Wiltshire, A., Chevallier, F., Maki, T., Nakamura, T., Niwa, Y., and Rödenbeck, C.: Land use change and El Niño-Southern Oscillation drive decadal carbon balance shifts in Southeast Asia, Nat. Commun., 9, 1154, https://doi.org/10.1038/s41467-018-03374$\mathrm{x}, 2018$.

Konovalov, I. B., Berezin, E. V., Ciais, P., Broquet, G., Beekmann, M., Hadji-Lazaro, J., Clerbaux, C., Andreae, M. O., Kaiser, J. W., and Schulze, E.-D.: Constraining $\mathrm{CO}_{2}$ emissions from open biomass burning by satellite observations of co-emitted species: a method and its application to wildfires in Siberia, Atmos. Chem. Phys., 14, 10383-10410, https://doi.org/10.5194/acp-14-103832014, 2014.

Konovalov, I. B., Lvova, D. A., Beekmann, M., Jethva, H., Mikhailov, E. F., Paris, J.-D., Belan, B. D., Kozlov, V. S., Ciais, P., and Andreae, M. O.: Estimation of black carbon emissions from Siberian fires using satellite observations of absorption and extinction optical depths, Atmos. Chem. Phys., 18, 1488914924, https://doi.org/10.5194/acp-18-14889-2018, 2018.

Korontzi, S., McCarty, J., Loboda, T., Kumar, S., and Justice, C.: Global distribution of agricultural fire in croplands from 3 years of Moderate Resolution Imaging Spectroradiometer (MODIS) data, Global Biogeochem. Cy., 20, GB2021, https://doi.org/10.1029/2005GB002529, 2006.

Krinner, G., Viovy, N., de Noblet-Ducoudré, N., Ogée, J., Polcher, J., Friedlingstein, P., Ciais, P., Sitch, S., and Prentice, I. C.: A dynamic global vegetation model for studies of the coupled atmosphere-biosphere system, Global Biogeochem. Cy., 19, 133, https://doi.org/10.1029/2003GB002199, 2005.

Krol, M., Peters, W., Hooghiemstra, P., George, M., Clerbaux, C., Hurtmans, D., McInerney, D., Sedano, F., Bergamaschi, P., El Hajj, M., Kaiser, J. W., Fisher, D., Yershov, V., and Muller, J.-P.: How much CO was emitted by the 2010 fires around Moscow?, Atmos. Chem. Phys., 13, 4737-4747, https://doi.org/10.5194/acp-13-4737-2013, 2013.

Lamarque, J.-F., Bond, T. C., Eyring, V., Granier, C., Heil, A., Klimont, Z., Lee, D., Liousse, C., Mieville, A., Owen, B., Schultz, M. G., Shindell, D., Smith, S. J., Stehfest, E., Van Aardenne, J., Cooper, O. R., Kainuma, M., Mahowald, N., McConnell, J. R., Naik, V., Riahi, K., and van Vuuren, D. P.: Historical (1850-2000) gridded anthropogenic and biomass burning emissions of reactive gases and aerosols: methodology and application, Atmos. Chem. Phys., 10, 7017-7039, https://doi.org/10.5194/acp-10-7017-2010, 2010.

Lasslop, G., Thonicke, K., and Kloster, S.: SPITFIRE within the MPI Earth system model: Model development and evaluation, J. Adv. Model Earth Sy., 6, 740-755, https://doi.org/10.1002/2013MS000284, 2014.

Lawrence, D. M., Hurtt, G. C., Arneth, A., Brovkin, V., Calvin, K. V., Jones, A. D., Jones, C. D., Lawrence, P. J., de NobletDucoudré, N., Pongratz, J., Seneviratne, S. I., and Shevliakova, E.: The Land Use Model Intercomparison Project (LUMIP) contribution to CMIP6: rationale and experimental design, Geosci.
Model Dev., 9, 2973-2998, https://doi.org/10.5194/gmd-9-29732016, 2016.

Lawrence, P. J. and Chase, T. N. : Representing a new MODIS consistent land surface in the Community Land Model (CLM 3.0), J. Geophys. Res., 112, G01023, https://doi.org/10.1029/2006JG000168, 2007.

Legrand, M., McConnell, J., Fischer, H., Wolff, E. W., Preunkert, S., Arienzo, M., Chellman, N., Leuenberger, D., Maselli, O., Place, P., Sigl, M., Schüpbach, S., and Flannigan, M.: Boreal fire records in Northern Hemisphere ice cores: a review, Clim. Past, 12, 2033-2059, https://doi.org/10.5194/cp-12-2033-2016, 2016.

Lehsten, V., Tansey, K., Balzter, H., Thonicke, K., Spessa, A., Weber, U., Smith, B., and Arneth, A.: Estimating carbon emissions from African wildfires, Biogeosciences, 6, 349-360, https://doi.org/10.5194/bg-6-349-2009, 2009.

Lelieveld, J., Evans, J. S., Fnais, M., Giannadaki, D., and Pozzer, A.: The con- tribution of outdoor air pollution sources to premature mortality on a global scale, Nature, 525, 367-371, 2015.

Le Page, Y., Morton, D., Bond-Lamberty, B., Pereira, J. M. C., and Hurtt, G.: HESFIRE: a global fire model to explore the role of anthropogenic and weather drivers, Biogeosciences, 12, 887-903, https://doi.org/10.5194/bg-12-887-2015, 2015.

Le Page, Y., Morton, D., Hartin, C., Bond-Lamberty, B., Pereira, J. M. C., Hurtt, G., and Asrar, G.: Synergy between land use and climate change increases future fire risk in Amazon forests, Earth Syst. Dynam., 8, 1237-1246, https://doi.org/10.5194/esd8-1237-2017, 2017.

Le Quéré, C., Peters, G. P., Andres, R. J., Andrew, R. M., Boden, T. A., Ciais, P., Friedlingstein, P., Houghton, R. A., Marland, G., Moriarty, R., Sitch, S., Tans, P., Arneth, A., Arvanitis, A., Bakker, D. C. E., Bopp, L., Canadell, J. G., Chini, L. P., Doney, S. C., Harper, A., Harris, I., House, J. I., Jain, A. K., Jones, S. D., Kato, E., Keeling, R. F., Klein Goldewijk, K., Körtzinger, A., Koven, C., Lefèvre, N., Maignan, F., Omar, A., Ono, T., Park, G.-H., Pfeil, B., Poulter, B., Raupach, M. R., Regnier, P., Rödenbeck, C., Saito, S., Schwinger, J., Segschneider, J., Stocker, B. D., Takahashi, T., Tilbrook, B., van Heuven, S., Viovy, N., Wanninkhof, R., Wiltshire, A., and Zaehle, S.: Global carbon budget 2013, Earth Syst. Sci. Data, 6, 235-263, https://doi.org/10.5194/essd6-235-2014, 2014.

Levis, S., Bonan, G. B., Vertenstein, M., and Oleson, K. W.: The Community Land Model's dynamic global vegetation model (CLM-DGVM): Technical description and user's guide, NCAR Tech. Note TN-459 IA, Terrestrial Sciences Section, Boulder, Colorado, 2004.

Li, F. and Lawrence, D. M.: Role of fire in the global land water budget during the 20th century through changing ecosystems, J. Climate, 30, 1893-908, 2017.

Li, F., Zeng, X. D., and Levis, S.: A process-based fire parameterization of intermediate complexity in a Dynamic Global Vegetation Model, Biogeosciences, 9, 2761-2780, https://doi.org/10.5194/bg-9-2761-2012, 2012.

Li, F., Levis, S., and Ward, D. S.: Quantifying the role of fire in the Earth system - Part 1: Improved global fire modeling in the Community Earth System Model (CESM1), Biogeosciences, 10, 2293-2314, https://doi.org/10.5194/bg-10-2293-2013, 2013.

Li, F., Lawrence, D. M., and Bond-Lamberty, B.: Human impacts on 20th century fire dynamics and implications for global carbon and water trajectories, Global Planet. Change, 162, 18-27, 2018. 
Li, F., Rabin, S. S., Val Martin, M., Hantson, S., Andreae, M. O., Arneth, A., Lasslop, G., Yue, C., Bachelet, D., Forrest, M., Kaiser, J. W., Kluzek, E., Liu, X., Melton, J. R., Ward, D. S., Darmenov, A., Hickler, T., Ichoku, C., Magi, B. I., Sitch, S., van der Werf, G. R., and Wiedinmyer, C.: Model outputs: Historical (17002012) Global Multi-model Estimates of the Fire Emissions from the Fire Modeling Intercomparison Project (FireMIP) (Version 1.0.1), Zenodo, https://doi.org/10.5281/zenodo.3386620, 2019.

Lindeskog, M., Arneth, A., Bondeau, A., Waha, K., Seaquist, J., Olin, S., and Smith, B.: Implications of accounting for land use in simulations of ecosystem carbon cycling in Africa, Earth Syst. Dynam., 4, 385-407, https://doi.org/10.5194/esd-4-3852013, 2013.

Magi, B. I., Rabin, S., Shevliakova, E., and Pacala, S.: Separating agricultural and non-agricultural fire seasonality at regional scales, Biogeosciences, 9, 3003-3012, https://doi.org/10.5194/bg-9-3003-2012, 2012.

Mahowald, N., Jickells, T. D., Baker, A. R., Artaxo, P., BenitezNelson, C. R., Bergametti, G., Bond, T. C., Chen, Y., Cohen, D. D., Herut, B., Kubilay, N., Losno, R., Luo, C., Maenhaut, W., McGee, K. A., Okin, G. S., Siefert, R. L., and Tsukuda, S.: Global distribution of atmospheric phosphorus sources, concentrations and deposition rates, and anthropogenic impacts, Global Biogeochem. Cy., 22, GB4026, https://doi.org/10.1029/2008GB003240, 2008.

Mangeon, S., Voulgarakis, A., Gilham, R., Harper, A., Sitch, S., and Folberth, G.: INFERNO: a fire and emissions scheme for the UK Met Office's Unified Model, Geosci. Model Dev., 9, 2685-2700, https://doi.org/10.5194/gmd-9-2685-2016, 2016.

Mao, J. F., Wang, B., and Dai, Y. J.: Sensitivity of the carbon storage of potential vegetation to historical climate variability and $\mathrm{CO}_{2}$ in continental China, Adv. Atmos. Sci., 26, 87-100, 2009.

Marlier, M. E., DeFries, R. S., Voulgarakis, A., Kinney, P. L., Randerson, J. T., Shindell, D. T., Chen, Y., and Faluvegi, G.: El Niño and health risks from landscape fire emissions in southeast Asia, Nat. Clim. Change, 3, 131-136, 2013.

Marlon, J. R., Bartlein, P. J., Carcaillet, C., Gavin, D. G., Harrison, S. P., Higuera, P. E., Joos, F., Power, M. J., and Prentice, I. C.: Climate and human influences on global biomass burning over the past two millennia, Nat. Geosci., 1, 697-702, https://doi.org/10.1038/ngeo313, 2008.

Marlon, J. R., Kelly, R., Daniau, A.-L., Vannière, B., Power, M. J., Bartlein, P., Higuera, P., Blarquez, O., Brewer, S., Brücher, T., Feurdean, A., Romera, G. G., Iglesias, V., Maezumi, S. Y., Magi, B., Courtney Mustaphi, C. J., and Zhihai, T.: Reconstructions of biomass burning from sediment-charcoal records to improve data-model comparisons, Biogeosciences, 13, 3225-3244, https://doi.org/10.5194/bg-13-3225-2016, 2016.

McKendry, I. G., Christen, A., Lee, S.-C., Ferrara, M., Strawbridge, K. B., O'Neill, N., and Black, A.: Impacts of an intense wildfire smoke episode on surface radiation, energy and carbon fluxes in southwestern British Columbia, Canada, Atmos. Chem. Phys., 19, 835-846, https://doi.org/10.5194/acp-19-835-2019, 2019.

McConnell, J. R., Edwards, R., Kok, G. L., Flanner, M. G., Zender, C. S., Saltzman, E. S., Banta, J. R., Pasteris, D. R., Carter, M. M., and Kahl, J. D. W.: 20th-century industrial black carbon emissions altered arctic climate forcing, Science, 317, 1381-1384, https://doi.org/10.1126/science.1144856, 2007.
Melton, J. R. and Arora, V. K.: Competition between plant functional types in the Canadian Terrestrial Ecosystem Model (CTEM) v. 2.0, Geosci. Model Dev., 9, 323-361, https://doi.org/10.5194/gmd-9-323-2016, 2016.

Mieville, A., Granier, C., Liousse, C., Guillaume, B., Mouillot, F., Lamarque, J.-F., Grégoire, J.-M., and Pétron, G.: Emissions of gases and particles from biomass burning during the 20th century using satellite data and an historical reconstruction, Atmos. Environ., 44, 1469-1477, https://doi.org/10.1016/j.atmosenv.2010.01.011, 2010.

Mouillot, F. and Field, C. B.: Fire history and the global carbon budget: $1^{\circ} \times 1^{\circ}$ fire history reconstruction for the 20th century, Glob. Change Biol., 11, 398-420, https://doi.org/10.1111/j.13652486.2005.00920.x, 2005.

Nemani, R. R. and Running, S. W.: Implementation of a hierarchical global vegetation classification in ecosystem function models, J. Veg. Sci., 7, 337-346, 1996.

Oleson, K., Lawrence, D. M., Bonan, G. B., Drewniak, B., Huang, M., Koven, C. D., Levis, S., Li, F., Riley, W. J., Subin, Z. M., Swenson, S. C., Thornton, P. E., Bozbiyik, A., Fisher, R. A., Heald, C. L., Kluzek, E., Lamarque, J.-F., Lawrence, P. J., Leung, L. R., Lipscomb, W., Muszala, S., Ricciuto, D. M., Sacks, W. J., Sun, Y., Tang, J., and Yang, Z.-L.: Technical Description of version 4.5 of the Community Land Model (CLM), Tech. Rep. NCAR/TN-503+STR NCAR, Boulder, CO, USA, 434 pp., 2013.

Parisien, M., Miller, C., Parks, S. A., DeLancey, E. R., Robinne, F., and Flannigan, M. D.: The spatially varying influence of humans on fire probability in North America, Environ. Res. Lett., 11, 075005, https://doi.org/10.1088/1748-9326/11/7/075005, 2016.

Pechony, O. and Shindell, D. T.: Driving forces of global wildfires over the past millennium and the forthcoming century, P. Natl. Acad. Sci. USA, 107, 19167-19170, 2010.

Pfeiffer, M., Spessa, A., and Kaplan, J. O.: A model for global biomass burning in preindustrial time: LPJ-LMfire (v1.0), Geosci. Model Dev., 6, 643-685, https://doi.org/10.5194/gmd-6643-2013, 2013.

Rabin, S. S., Melton, J. R., Lasslop, G., Bachelet, D., Forrest, M., Hantson, S., Kaplan, J. O., Li, F., Mangeon, S., Ward, D. S., Yue, C., Arora, V. K., Hickler, T., Kloster, S., Knorr, W., Nieradzik, L., Spessa, A., Folberth, G. A., Sheehan, T., Voulgarakis, A., Kelley, D. I., Prentice, I. C., Sitch, S., Harrison, S., and Arneth, A.: The Fire Modeling Intercomparison Project (FireMIP), phase 1: experimental and analytical protocols with detailed model descriptions, Geosci. Model Dev., 10, 11751197, https://doi.org/10.5194/gmd-10-1175-2017, 2017.

Rabin, S. S., Ward, D. S., Malyshev, S. L., Magi, B. I., Shevliakova, E., and Pacala, S. W.: A fire model with distinct crop, pasture, and non-agricultural burning: use of new data and a modelfitting algorithm for FINAL.1, Geosci. Model Dev., 11, 815-842, https://doi.org/10.5194/gmd-11-815-2018, 2018.

Reddington, C. L., Morgan, W. T., Darbyshire, E., Brito, J., Coe, H., Artaxo, P., Scott, C. E., Marsham, J., and Spracklen, D. V.: Biomass burning aerosol over the Amazon: analysis of aircraft, surface and satellite observations using a global aerosol model, Atmos. Chem. Phys., 19, 9125-9152, https://doi.org/10.5194/acp-19-9125-2019, 2019.

Randerson, J. T., Chen, Y., van der Werf, G. R., Rogers, B. M., and Morton, D. C.: Global burned area and biomass burning 
emissions from small fires, J. Geophys. Res., 117, G04012, https://doi.org/10.1029/2012JG002128, 2012.

Rothermel, R. C.: A mathematical model for predicting fire spread in wildland fuels, Res. Pap. INT-115, US Department of Agriculture, Ogden, UT, USA, 40 pp., 1972.

Schultz, M. G., Heil, A., Hoelzemann, J. J., Spessa, A., Thonicke, K., Goldammer, J. G., Held, A. C., Pereira, J. M. C., and van het Bolscher, M.: Global wildland fire emissions from 1960 to 2000, Global Biogeochem. Cy., 22, GB2002, https://doi.org/10.1029/2007GB003031, 2008.

Scott, A. C. and Glasspool, I. J.: The diversification of Palaeozoic fire systems and fluctuations in atmospheric oxygen concentration, P. Natl. Acad. Sci. USA, 103, 10861-10865, https://doi.org/10.1073/pnas.0604090103, 2006.

Sheehan, T., Bachelet, D., and Ferschweiler, K.: Projected major fire and vegetation changes in the Pacific Northwest of the conterminous United States under selected CMIP5 climate futures, Ecol. Model., 317, 16-29, https://doi.org/10.1016/j.ecolmodel.2015.08.023, 2015.

Smith, B., Wårlind, D., Arneth, A., Hickler, T., Leadley, P., Siltberg, J., and Zaehle, S.: Implications of incorporating $\mathrm{N}$ cycling and $\mathrm{N}$ limitations on primary production in an individualbased dynamic vegetation model, Biogeosciences, 11, 20272054, https://doi.org/10.5194/bg-11-2027-2014, 2014.

Stockwell, C. E., Christian, T. J., Goetz, J. D., Jayarathne, T., Bhave, P. V., Praveen, P. S., Adhikari, S., Maharjan, R., DeCarlo, P. F., Stone, E. A., Saikawa, E., Blake, D. R., Simpson, I. J., Yokelson, R. J., and Panday, A. K.: Nepal Ambient Monitoring and Source Testing Experiment (NAMaSTE): emissions of trace gases and light-absorbing carbon from wood and dung cooking fires, garbage and crop residue burning, brick kilns, and other sources, Atmos. Chem. Phys., 16, 11043-11081, https://doi.org/10.5194/acp-16-11043-2016, 2016.

Thonicke, K., Venevsky, S., Sitch, S., and Cramer, W.: The role of fire disturbance for global vegetation dynamics: Coupling fire into a Dynamic Global Vegetation Model, Global Ecol. Biogeogr., 10, 661-677, 2001.

Thonicke, K., Spessa, A., Prentice, I. C., Harrison, S. P., Dong, L., and Carmona-Moreno, C.: The influence of vegetation, fire spread and fire behaviour on biomass burning and trace gas emissions: results from a process-based model, Biogeosciences, 7, 1991-2011, https://doi.org/10.5194/bg-7-1991-2010, 2010.

Thornhill, G. D., Ryder, C. L., Highwood, E. J., Shaffrey, L. C., and Johnson, B. T.: The effect of South American biomass burning aerosol emissions on the regional climate, Atmos. Chem. Phys., 18, 5321-5342, https://doi.org/10.5194/acp-185321-2018, 2018.

Teckentrup, L., Harrison, S. P., Hantson, S., Heil, A., Melton, J. R., Forrest, M., Li, F., Yue, C., Arneth, A., Hickler, T., Sitch, S., and Lasslop, G.: Sensitivity of simulated historical burned area to environmental andanthropogenic controls: A comparison of seven fire models, Biogeosciences Discuss., https://doi.org/10.5194/bg-2019-42, in review, 2019.

Tian, H., Lu, C., Ciais, P., Michalak, A. M., Canadell, J. G., Saikawa, E., Huntzinger, D. N., Gurney, K., Sitch, S., Zhang, B., Yang, J., Bousquet, P., Bruhwiler, L., Chen, G., Dlugokencky, E., Friedlingstein, P., Melillo, J., Pan, S., Poulter, B., Prinn, R., Saunois, M., Schwalm, C. R., and Wofsy, S. C.: The terrestrial biosphere as a net source of greenhouse gases to the atmosphere, Nature, 531, 225-228, 2016.

Tosca, M. G., Randerson, J. T., and Zender, C. S.: Global impact of smoke aerosols from landscape fires on climate and the Hadley circulation, Atmos. Chem. Phys., 13, 5227-5241, https://doi.org/10.5194/acp-13-5227-2013, 2013.

Val Martin, M., Heald, C. L., Lamarque, J.-F., Tilmes, S., Emmons, L. K., and Schichtel, B. A.: How emissions, climate, and land use change will impact mid-century air quality over the United States: a focus on effects at national parks, Atmos. Chem. Phys., 15, 2805-2823, https://doi.org/10.5194/acp15-2805-2015, 2015.

van der Werf, G. R., Randerson, J. T., Giglio, L., Collatz, G. J., Kasibhatla, P. S., and Arellano Jr., A. F.: Interannual variability in global biomass burning emissions from 1997 to 2004, Atmos. Chem. Phys., 6, 3423-3441, https://doi.org/10.5194/acp-6-34232006, 2006.

van der Werf, G. R., Randerson, J. T., Giglio, L., Collatz, G. J., Mu, M., Kasibhatla, P. S., Morton, D. C., DeFries, R. S., Jin, Y., and van Leeuwen, T. T.: Global fire emissions and the contribution of deforestation, savanna, forest, agricultural, and peat fires (1997-2009), Atmos. Chem. Phys., 10, 11707-11735, https://doi.org/10.5194/acp-10-11707-2010, 2010.

van der Werf, G. R., Peters, W., van Leeuwen, T. T., and Giglio, L.: What could have caused pre-industrial biomass burning emissions to exceed current rates?, Clim. Past, 9, 289-306, https://doi.org/10.5194/cp-9-289-2013, 2013.

van der Werf, G. R., Randerson, J. T., Giglio, L., van Leeuwen, T. T., Chen, Y., Rogers, B. M., Mu, M., van Marle, M. J. E., Morton, D. C., Collatz, G. J., Yokelson, R. J., and Kasibhatla, P. S.: Global fire emissions estimates during 1997-2016, Earth Syst. Sci. Data, 9, 697-720, https://doi.org/10.5194/essd-9-697-2017, 2017.

van Marle, M. J. E., Field, R. D., van der Werf, G. R., Estrada de Wagt, I. A., Houghton, R. A., Rizzo, L. V., Artaxo, P., and Tsigaridis, K.: Fire and deforestation dynamics in Amazonia (1973-2014), Global Biogeochem. Cy., 31, 24-38, https://doi.org/10.1002/2016GB005445, 2017a.

van Marle, M. J. E., Kloster, S., Magi, B. I., Marlon, J. R., Daniau, A.-L., Field, R. D., Arneth, A., Forrest, M., Hantson, S., Kehrwald, N. M., Knorr, W., Lasslop, G., Li, F., Mangeon, S., Yue, C., Kaiser, J. W., and van der Werf, G. R.: Historic global biomass burning emissions for CMIP6 (BB4CMIP) based on merging satellite observations with proxies and fire models (1750-2015), Geosci. Model Dev., 10, 3329-3357, https://doi.org/10.5194/gmd-10-3329-2017, 2017b.

Wang, Z., Chappellaz, J., Park, K., and Mak, J. E.: Large variations in southern hemisphere biomass burning during the Last 650 years, Science, 330, 1663-1666, 2010.

Wang, Z., Chappellaz, J., Martinerie, P., Park, K., Petrenko, V., Witrant, E., Emmons, L. K., Blunier, T., Brenninkmeijer, C. A. M., and Mak, J. E.: The isotopic record of Northern Hemisphere atmospheric carbon monoxide since 1950: implications for the CO budget, Atmos. Chem. Phys., 12, 4365-4377, https://doi.org/10.5194/acp-12-4365-2012, 2012.

Ward, D. S., Kloster, S., Mahowald, N. M., Rogers, B. M., Randerson, J. T., and Hess, P. G.: The changing radiative forcing of fires: global model estimates for past, present and future, Atmos. Chem. Phys., 12, 10857-10886, https://doi.org/10.5194/acp-1210857-2012, 2012. 
Ward, D. S., Shevliakova, E., Malyshev, S., and Rabin, S.: Trends and variability of global fire emissions due to historical anthropogenic activities, Global Biogeochem. Cy., 32, 122-142, https://doi.org/10.1002/2017GB005787, 2018.

Wei, Y., Liu, S., Huntzinger, D. N., Michalak, A. M., Viovy, N., Post, W. M., Schwalm, C. R., Schaefer, K., Jacobson, A. R., Lu, C., Tian, H., Ricciuto, D. M., Cook, R. B., Mao, J., and Shi, X.: The North American Carbon Program Multi-scale Synthesis and Terrestrial Model Intercomparison Project - Part 2: Environmental driver data, Geosci. Model Dev., 7, 2875-2893, https://doi.org/10.5194/gmd-7-2875-2014, 2014.

Wiedinmyer, C., Akagi, S. K., Yokelson, R. J., Emmons, L. K., AlSaadi, J. A., Orlando, J. J., and Soja, A. J.: The Fire INventory from NCAR (FINN): a high resolution global model to estimate the emissions from open burning, Geosci. Model Dev., 4, 625641, https://doi.org/10.5194/gmd-4-625-2011, 2011.

Wu, Y., Han, Y., Voulgarakis, A., Wang, T., Li, M., Wang, Y., Xie, M., Zhuang, B., and Li, S.: An agricultural biomass burning episode in eastern China: Transport, optical properties, and impacts on regional air quality, J. Geophys. Res.-Atmos., 122, 2304-2324, https://doi.org/10.1002/2016JD025319, 2017.

Yang, J., Tian, H., Tao, B., Ren, W., Kush, J., Liu, Y., and Wang, Y.: Spatial and temporal patterns of global burned area in response to anthropogenic and environmental factors: Reconstructing global fire history for the 20th and early 21 st centuries, J. Geophys. Res.-Biogeo., 119, 249-263, https://doi.org/10.1002/2013JG002532, 2014.

Yokelson, R. J., Burling, I. R., Gilman, J. B., Warneke, C., Stockwell, C. E., de Gouw, J., Akagi, S. K., Urbanski, S. P., Veres, P., Roberts, J. M., Kuster, W. C., Reardon, J., Griffith, D. W. T., Johnson, T. J., Hosseini, S., Miller, J. W., Cocker III, D. R., Jung, H., and Weise, D. R.: Coupling field and laboratory measurements to estimate the emission factors of identified and unidentified trace gases for prescribed fires, Atmos. Chem. Phys., 13, 89-116, https://doi.org/10.5194/acp-13-89-2013, 2013.

Yue, C., Ciais, P., Cadule, P., Thonicke, K., Archibald, S., Poulter, B., Hao, W. M., Hantson, S., Mouillot, F., Friedlingstein, P., Maignan, F., and Viovy, N.: Modelling the role of fires in the terrestrial carbon balance by incorporating SPITFIRE into the global vegetation model ORCHIDEE - Part 1: simulating historical global burned area and fire regimes, Geosci. Model Dev., 7, 2747-2767, https://doi.org/10.5194/gmd-7-2747-2014, 2014.
Yue, C., Ciais, P., Cadule, P., Thonicke, K., and van Leeuwen, T. T.: Modelling the role of fires in the terrestrial carbon balance by incorporating SPITFIRE into the global vegetation model ORCHIDEE - Part 2: Carbon emissions and the role of fires in the global carbon balance, Geosci. Model Dev., 8, 1321-1338, https://doi.org/10.5194/gmd-8-1321-2015, 2015.

Yue, $X$. and Unger, N.: Fire air pollution reduces global terrestrial productivity, Nat. Commun., 9, 5413, https://doi.org/10.1038/s41467-018-07921-4, 2018.

Zennaro, P., Kehrwald, N., McConnell, J. R., Schüpbach, S., Maselli, O. J., Marlon, J., Vallelonga, P., Leuenberger, D., Zangrando, R., Spolaor, A., Borrotti, M., Barbaro, E., Gambaro, A., and Barbante, C.: Fire in ice: two millennia of boreal forest fire history from the Greenland NEEM ice core, Clim. Past, 10, 1905-1924, https://doi.org/10.5194/cp-10-1905-2014, 2014.

Zhang, F., Wang, J., Ichoku, C., Hyer, E. J., Yang, Z., Ge, C., Su, S., Zhang, X., Kondragunta, S., Kaiser, J. W., Wiedinmyer, C., and da Silva, A.: Sensitivity of mesoscale modeling of smoke direct radiative effect to the emission inventory: a case study in northern sub-Saharan African region, Environ. Res. Lett., 9, 075002, https://doi.org/10.1088/1748-9326/9/7/075002, 2014.

Zhang, T. R., Wooster, M. J., de Jong, M. C., and Xu, W. D.: How well does the "Small Fire Boost" methodology used within the GFED4.1s fire emissions database represent the timing, location and magnitude of agricultural burning?, Remote. Sens., 10, 823, https://doi.org/10.3390/rs10060823, 2018.

Zhu, Z., Piao, S., Myneni, R. B., Huang, M., Zeng, Z., Canadell, J. G., Ciais, P., Sitch, S., Friedlingstein, P., Arneth, A., Cao, C., Cheng, L., Kato, E., Koven, C., Li, Y., Lian, X., Liu, Y., Liu, R., Mao, J., Pan, Y., Peng, S., Peñuelas, J., Poulter, B., Pugh, T. A. M., Stocker, B. D., Viovy, N., Wang, X., Wang, Y., Xiao, Z., Yang, H., Zaehle, S., and Zeng, N.: Greening of the Earth and its drivers, Nat. Clim. Change, 6, 791-795, 2016. 